\title{
Rescue of Learning and Memory Deficits in the Human Nonsyndromic Intellectual Disability Cereblon Knock-Out Mouse Model by Targeting the AMP-Activated Protein Kinase-mTORC1 Translational Pathway
}

\author{
[CCharlotte C. Bavley, ${ }^{1,2,3 *}$-Richard C. Rice, ${ }^{1,3 *}$ Delaney K. Fischer, ${ }^{1,3}{ }^{\circledR}$ Amanda K. Fakira, ${ }^{4}$ Maureen Byrne, \\ Maria Kosovsky, ${ }^{1}$ Bryant K. Rizzo, ${ }^{1,3}$ Dolores Del Prete, ${ }^{5}$ Armin Alaedini, ${ }^{3,6}$ Jose A. Morón, ${ }^{4}$ Joseph J. Higgins, ${ }^{1,3}$ \\ Luciano D'Adamio, ${ }^{7}$ and Anjali M. Rajadhyaksha ${ }^{1,2,3}$ \\ ${ }^{1}$ Pediatric Neurology, Department of Pediatrics, ${ }^{2}$ Feil Family Brain and Mind Research Institute, ${ }^{3}$ Weill Cornell Autism Research Program, Weill Cornell \\ Medical College, Cornell University, New York, NY 10065, ${ }^{4}$ Department of Anesthesiology, Vagelos College of Physicians and Surgeons, Columbia \\ University, New York, New York 10032, ${ }^{5}$ Department of Microbiology and Immunology, Albert Einstein College of Medicine, Bronx, New York 10461, \\ ${ }^{6}$ Department of Medicine, Columbia University Medical Center, New York, New York 10032, and ${ }^{7}$ Department of Pharmacology, Physiology and \\ Neuroscience, New Jersey Medical School, Rutgers University, Newark, NJ 07103
}

\begin{abstract}
A homozygous nonsense mutation in the cereblon $(C R B N)$ gene results in autosomal recessive, nonsyndromic intellectual disability that is devoid of other phenotypic features, suggesting a critical role of CRBN in mediating learning and memory. In this study, we demonstrate that adult male $\mathrm{Crbn}$ knock-out $\left(\mathrm{Crbn}^{\mathrm{KO}}\right)$ mice exhibit deficits in hippocampal-dependent learning and memory tasks that are recapitulated by focal knock-out of $\mathrm{Crbn}$ in the adult dorsal hippocampus, with no changes in social or repetitive behavior. Cellular studies identify deficits in long-term potentiation at Schaffer collateral CA1 synapses. We further show that Crbn is robustly expressed in the mouse hippocampus and $\mathrm{Crbn}{ }^{\mathrm{KO}}$ mice exhibit hyperphosphorylated levels of AMPK $\alpha$ (Thr172). Examination of processes downstream of AMP-activated protein kinase (AMPK) finds that $\mathrm{Crbn}{ }^{\mathrm{KO}}$ mice have a selective impairment in mediators of the mTORC1 translation initiation pathway in parallel with lower protein levels of postsynaptic density glutamatergic proteins and higher levels of excitatory presynaptic markers in the hippocampus with no change in markers of the unfolded protein response or autophagy pathways. Acute pharmacological inhibition of AMPK activity in adult $\mathrm{Crbn}{ }^{\mathrm{KO}}$ mice rescues learning and memory deficits and normalizes hippocampal mTORC1 activity and postsynaptic glutamatergic proteins without altering excitatory presynaptic markers. Thus, this study identifies that loss of $\mathrm{Crbn}$ results in learning, memory, and synaptic defects as a consequence of exaggerated AMPK activity, inhibition of mTORC1 signaling, and decreased glutamatergic synaptic proteins. Thus, $\mathrm{Crbn}{ }^{\mathrm{KO}}$ mice serve as an ideal model of intellectual disability to further explore molecular mechanisms of learning and memory.
\end{abstract}

Key words: AMPK; cereblon; excitatory; glutamatergic; intellectual disability; mTOR

Significance Statement

Intellectual disability (ID) is one of the most common neurodevelopmental disorders. The cereblon (CRBN) gene has been linked to autosomal recessive, nonsyndromic ID, characterized by an intelligence quotient between 50 and 70 but devoid of other phenotypic features, making cereblon an ideal protein for the study of the fundamental aspects of learning and memory. Here, using the cereblon knock-out mouse model, we show that cereblon deficiency disrupts learning, memory, and synaptic function via AMP-activated protein kinase hyperactivity, downregulation of mTORC1, and dysregulation of excitatory synapses, with no changes in social or repetitive behaviors, consistent with findings in the human population. This establishes the cereblon knockout mouse as a model of pure ID without the confounding behavioral phenotypes associated with other current models of ID. 


\section{Introduction}

Intellectual disability (ID) is the most common childhood neurodevelopmental disorder that affects learning ability, impairs cognitive functioning, and is defined by an intelligence quotient (IQ) below 70. Clinically, ID is classified into syndromic ID, which co-occurs with other phenotypic features, or nonsyndromic ID, with cognitive impairment as the sole abnormality. In recent years, ID has been predominantly studied as a component of syndromic neurodevelopmental disorders such as fragile $\mathrm{X}$ syndrome, Down syndrome, Rett syndrome, and autism spectrum disorder (ASDs). However, given that these ID-associated disorders manifest with deficits in multiple brain processes, studying nonsyndromic ID can provide a foundation to understand the fundamental aspects of learning and memory formation.

Approximately 25\% of genetic forms of ID are inherited as autosomal recessive traits (Khan et al., 2016). One such autosomal recessive nonsyndromic ID (ARNSID) is caused by a homozygous nonsense variant in the human cereblon gene (CRBN:c.1255C > T; p.Arg419Ter; NM_016302.3) located on chromosome 3p26.2 (OMIM:609262) and characterized by IQs between 50 and 70 (Higgins et al., 2004a,b). In recent years, CRBN has been identified as a substrate receptor of the E3 ubiquitin ligase complex in multiple systems (Ito et al., 2010; Chang and Stewart, 2011) including the mouse brain (Del Prete et al., 2016). The CRBN gene encodes a 442 amino acid protein with the nonsense variant resulting in a premature stop codon that generates truncated CRBN, lacking the last 24 amino acids. While still able to assemble into the E3 ubiquitin ligase complex, truncated CRBN undergoes proteosomal degradation due to an enhanced level of autoubiquitination (Xu et al., 2013). This suggests that deficient CRBN levels and function may be the underlying cause of ID in patients harboring this mutation. This is supported by animal studies showing impaired hippocampal-dependent fear memory in Crbn-deficient mice (Rajadhyaksha et al., 2012). However, the mechanisms by which defects in CRBN affect cognitive processes remain unknown.

Previous studies have highlighted multiple cellular functions for Crbn in addition to its role in ubiquitination (Kim et al., 2016). One potential mechanism for Crbn's role in learning and memory involves the AMP-activated protein kinase (AMPK). AMPK, well known for its role as an energy sensor in multiple systems (Hardie et al., 2012), has been implicated in numerous brain disorders, including memory-related deficits in Alzheimer's disease mouse models (Ma et al., 2014). Under normal conditions, Crbn directly binds the catalytic subunit AMPK, reducing its affinity for its regulatory $\alpha$ subunit, resulting in suppression of its phosphorylation at Thr172 and subsequent activity (Xu et al., 2013; Lee et al., 2014). Heightened activity of AMPK under con-

Received Feb. 25, 2017; revised Jan. 3, 2018; accepted Jan. 27, 2018.

Author contributions: C.C.B., R.C.R., D.K.F., A.K.F., A.A., J.A.M., J.J.H., L.D., and A.M.R. designed research; C.C.B., R.C.R., D.K.F., A.K.F., M.B., M.K., D.D.P., and B.K.R. performed research; C.C.B., R.C.R., D.K.F., A.K.F., M.B., M.K., J.A.M., and A.M.R. analyzed data; C.C.B., R.C.R., D.K.F., A.A., J.A.M., J.J.H., L.D., and A.M.R. wrote the paper; A.A., J.A.M., J.J.H.,and L.D. discussed and commented on the mansucript.

This work is supported by grants from the March of Dimes (J.J.H., A.M.R.), The Hartwell Foundation (A.M.R.), the Weill Cornell Autism Research Program (A.M.R.), BrightFocus Foundation (D.D.P.) and NIH Grants R01AG952286 (L.D., A.M.R.), R01DA029122 (A.M.R.), R01DA041781 (J.A.M.), R01DA042499, R21DA042581 (J.A.M.), and R21DA041883 (J.A.M.). We thank Caitlin Burgdorf and Jonathan Hackett for technical assistance.

*C.C.B. and R.C.R. equally contributed to this work.

The authors declare no competing financial interests.

Correspondence should be addressed to Dr. Anjali Rajadhyaksha, Pediatric Neurology, Department of Pediatrics, Weill Cornell Medical College, Cornell University, 1300 York Avenue, LC-604, New York, NY 10065. E-mail: amr2011@med.cornell.edu.

DOI:10.1523/JNEUROSCI.0599-17.2018

Copyright $\odot 2018$ the authors $\quad 0270-6474 / 18 / 382781-16 \$ 15.00 / 0$ ditions of metabolic stress impairs learning, memory, and synaptic plasticity via coordination of several downstream pathways, including suppression of dendritic mRNA translation through inhibition of mTOR (Inoki et al., 2003; Hoeffer and Klann, 2010; Rosso et al., 2016) and eEF2 kinase pathways (Horman et al., 2002; Hardie, 2004), as well as activation of the unfolded protein response (UPR) (Appenzeller-Herzog and Hall, 2012) and autophagy (Nixon, 2006; Hegde, 2017). These pathways have been linked to neuronal processes, such as long-term potentiation (LTP), dendritic protein synthesis, excitatory/inhibitory (E/I) balance, and spine dysgenesis (Hoeffer and Klann, 2010; Buffington et al., 2014; Santini and Klann, 2014; Mullins et al., 2016), which are dysregulated in disorders with deficits in learning and memory.

Given that the CRBN R419X mutation results in loss of protein (Xu et al., 2013), in this study, we use Crbn knock-out $\left(\mathrm{Crbn}{ }^{\mathrm{KO}}\right)$ mice to examine behaviors related to learning and memory in addition to processes downstream of AMPK, including the mTOR pathway, the eEF2 kinase pathway, UPR, and autophagy. We report that loss of Crbn leads to deficits in learning and memory via hyperphosphorylated AMPK and downstream inhibition of mTORC1-mediated mRNA translation of glutamatergic postsynaptic proteins within the hippocampus, while having no effect on the eEF2 pathway, UPR activity, or autophagy.

\section{Materials and Methods}

Animals. Male $\mathrm{Crbn}{ }^{\mathrm{KO}}$ mice and wild-type littermates, on the $\mathrm{C} 57 \mathrm{Bl} / 6 \mathrm{~J}$ (Jackson Laboratory) background, were generated by crossing Crbn-

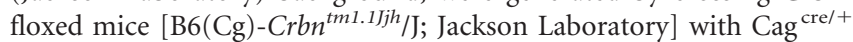
deleter mice to generate mice where Cre recombinase deletes $\mathrm{Crbn}$ in all tissues (i.e., germ line). All mice were 8-12 weeks old at the start of the experiments. Animals were group housed, maintained on a $12 \mathrm{~h}$ light/ dark cycle, and had food and water available ad libitum. All animal procedures were conducted in accordance with the institution's Animal Care and Use Committee following the National Institutes of Health Guidelines for the Care and Use of Laboratory Animals.

Stereotaxic viral vector delivery. Focal deletion of Crbn in the dorsal hippocampus was achieved using bilateral stereotaxic microinjection as described previously (Burgdorf et al., 2017). Briefly, either AAV2/2-GFP or AAV2/2-Cre-GFP (Vector Biolabs) was microinjected into the dorsal hippocampus of adult $\mathrm{Cr} b n$-floxed mice at a rate of $0.1 \mu \mathrm{l} / \mathrm{min}$ for a total volume of $0.2 \mu \mathrm{l} / \mathrm{hemisphere}$. Stereotaxic coordinates for the dorsal hippocampus were $-3.5 \mathrm{~mm}$ anteroposterior, $\pm 2.8 \mathrm{~mm}$ mediolateral, and $-4.2 \mathrm{~mm}$ dorsoventral, angled $4^{\circ}$ toward the midline in the coronal plane (Paxinos and Franklin, 2004). Behavioral experiments began after a minimum of 3 weeks to allow for maximal gene deletion. Fluorescence immunohistochemistry for GFP was used to confirm injection placement (1:5000 chicken anti-GFP primary antibody, AB_10000240, Aves Labs; 1:400 goat anti-chicken Alexa Fluor 488, AB_2534096, Invitrogen). Animals with improper bilateral injection placement were excluded from behavioral data analysis. Efficiency of $\mathrm{Crbn}$ deletion was evaluated using quantitative real-time PCR (qRT-PCR) to measure Crbn mRNA levels using Crbn-specific primers (QT00159285; Qiagen).

Drugs. Compound C (EMD Chemicals) was dissolved in saline (1\% DMSO) at a concentration of $1 \mathrm{mg} / \mathrm{kg}$ and was injected intraperitoneally at $0.01 \mathrm{ml} / \mathrm{g}$ body weight for a final dose of $10 \mathrm{mg} / \mathrm{kg}$. Compound $\mathrm{C}$ was injected $25 \mathrm{~min}$ before the start of behavioral testing or tissue collection.

Generation of Crbn antibody. Rabbit polyclonal antibody was generated against a peptide (YLGADMEEFHGRTLHDDDS) corresponding to the cereblon protein's amino acids 62-80 in mouse (accession number NP_780566.1) and rat (accession number EDL91471.1) and amino acids 58-76 in human (accession number AAH67811.1). For animal immunizations, a cysteine was added to the amino terminus of the peptide to use the thiol group of this amino acid for conjugation to keyhole limpet hemocyanin (ProSci). Following animal immunization and collection of antiserum, anti-cereblon antibodies were affinity purified (ProSci). 
Immunohistochemistry. Mice were first perfused with $\sim 20-30 \mathrm{ml}$ of Sorenson's buffer followed by $30-50 \mathrm{ml}$ of $4 \%$ paraformaldehyde (PFA) fixative. Brains were quickly removed and fixed in $4 \%$ PFA in Sorenson's buffer overnight at $4^{\circ} \mathrm{C}$. Brains were sectioned (30 $\mu \mathrm{m}$ thick) with a vibratome, and slices were washed with PBS and incubated for $90 \mathrm{~min}$ with preblocking agent containing 10\% normal goat serum in PBS and $0.2 \%$ Triton. Slides were washed in PBS and incubated overnight with primary antibodies NeuN (1:300, AB_2149209, Millipore) and Crbn (1: 200) prepared in preblocking agent solution. After washes, sections were incubated with secondary Alexa Fluor 488 and 594 fluorescent antibodies (Invitrogen) at room temperature for $2 \mathrm{~h}$. After washes, slices were fixed on glass slides and incubated with ProLong Gold antifade (Invitrogen). Images were captured using an SP5 confocal microscope (Leica) under $10 \times$ mosaic magnification.

Morris water maze. A modified version of the Morris water maze (MWM) was used (Morris et al., 1982). For data in Figure 2, $A$ and $B$, a pool (diameter, $96.6 \mathrm{~cm}$; depth, $36.8 \mathrm{~cm})$ was filled with water $\left(25-26^{\circ} \mathrm{C}\right)$ and clouded with nontoxic white tempura paint to conceal the position of an underwater escape platform, which was submerged $1-1.5 \mathrm{~cm}$ beneath the surface. Extramaze cues were placed surrounding the maze. The maze was virtually divided into three zones, with one designated the "goal" for each mouse. Each zone surrounded the potential location of the platform during training. Mice were given $60 \mathrm{~s}$ to habituate to the MWM and then underwent $4 \mathrm{~d}$ of training with three trials each day. For experiments in Figure 3, $B$ and $C$, the maze (diameter, $183 \mathrm{~cm}$; depth, $36.8 \mathrm{~cm}$ ) was virtually divided into four zones. Training consisted of $5 \mathrm{~d}$ with four trials on each day. Latency to locate the platform was recorded. Forty-eight hours after the last training trial, mice were given a long-term memory probe test, during which the hidden platform was removed and the time spent in each zone of the maze was recorded. All trials were videotaped using a camera mounted above the maze, and behavior was tracked using ANY-maze software (Stoelting).

Water-based Y maze. The water-based Y maze was used to measure learning and long-term memory. The apparatus consisted of three equally sized plastic arms $(33.0 \times 7.6 \times 38.1 \mathrm{~cm})$, separated by a $120^{\circ}$ angle. The maze was filled with water $\left(25-26^{\circ} \mathrm{C}\right)$ to a height of $\sim 22.9 \mathrm{~cm}$ and clouded with nontoxic white tempura paint. Each mouse was given three 60 s habituation trials on day 1 , followed by seven training trials on day 2 , during which a hidden platform was submerged below the opaque water and the mouse was placed in an adjacent arm. The starting location and location of the platform remained consistent throughout trials for each mouse, but were randomized between animals. Latency to locate the hidden platform was recorded. Long-term memory (five trials) was tested $24 \mathrm{~h}$ after the final training trial.

Spontaneous alternation. Spontaneous alternation was used to measure working memory. The Y-maze apparatus was used (see above, Water-based Y maze). Mice were placed in the center of the apparatus and allowed to explore for $5 \mathrm{~min}$. Each animal's path was recorded by the experimenter. A spontaneous alternation occurred whenever a mouse entered all three arms of the maze in succession without repeating entry into any of the arms. Percentage of spontaneous alternations was calculated $\left[100^{*}\right.$ (number of spontaneous alternations/number of potential alternations)]. The maze was cleaned with $70 \%$ ethanol between subjects.

Three-chambered social interaction and social preference. Social interaction and social preference tests were conducted to analyze sociability in a rectangular plastic apparatus $(67.3 \times 41.9 \times 22.9 \mathrm{~cm})$ containing three separate chambers, which could be divided by removable Plexiglas walls $(40.6 \times 15.2 \mathrm{~cm})$. With the walls in place, mice were allowed a $60 \mathrm{~s}$ habituation to the center chamber. Following, the walls were removed, and mice were given a $5 \mathrm{~min}$ habituation to the entire three-chamber apparatus. During the social interaction test, a cup containing a stranger mouse and a cup containing a novel object were placed in the outer chambers of the apparatus. The experimental mouse was given $5 \mathrm{~min}$ to explore freely, and times spent interacting with the cup containing the stranger mouse and the cup containing the novel object were recorded using ANY-maze software (Stoelting). During the social preference test, a cup containing a stranger mouse and a cup containing a familiar mouse were placed in the outer chambers of the apparatus, and the experimental mouse was given $5 \mathrm{~min}$ to explore freely. Time spent with each cup was recorded. The apparatus and cups were cleaned with $70 \%$ ethanol between subjects.

Grooming assay. Mice were habituated to the test chamber for $30 \mathrm{~min}$ and videotaped for $5 \mathrm{~min}$ to assess their baseline activity. Mice were then sprayed three times on the head with a handheld water spray bottle and videotaped for a $5 \mathrm{~min}$ period of time. Video clips were viewed and scored by independent and blinded investigators, and the amount of time spent grooming was recorded with a stopwatch.

Contextual fear conditioning. Contextual fear conditioning was conducted as described by Rajadhyaksha et al. (2012). On day 1, mice were placed in the conditioning apparatus containing a shock chamber enclosed by a sound-attenuated box (Coulbourn). Animals were given $90 \mathrm{~s}$ for habituation, followed by five conditioning trials, each consisting of a $30 \mathrm{~s}$ tone presentation $(2.9 \mathrm{kHz}, 84 \mathrm{~dB})$ that coterminated with a $1 \mathrm{~s}$ foot shock $(0.7 \mathrm{~mA})$. Conditioning trials were separated by increasing intertrial intervals. The shock chamber was cleaned between animals with ethanol and a $0.1 \%$ peppermint scent. On day 2 , mice were placed back into the shock chamber scented with $0.1 \%$ peppermint, and after $1 \mathrm{~min}$ of habituation, freezing was measured during a $4.5 \mathrm{~min}$ contextual recall test. Behavior was recorded using a camera mounted above the apparatus, and freezing was measured using FreezeView automated analysis (Coulbourn Instruments).

Long-term potentiation. LTP and input-output curves were obtained as published previously (Xia et al., 2011). Brains were quickly dissected in a semifrozen sectioning solution that contained the following (in $\mathrm{mM}$ ): 175 sucrose, $7 \mathrm{MgCl}_{2}, 2.5 \mathrm{KCl}, 1.2 \mathrm{NaH}_{2} \mathrm{PO}_{4}, 0.5 \mathrm{CaCl}_{2}, 26 \mathrm{NaHCO}_{3}$, and 25 glucose. Brains were sliced at $350 \mu \mathrm{m}$ thickness while submerged in an ice-cold sectioning solution. Sagittal sections were transferred to beakers that contained artificial CSF (aCSF) and incubated at $30 \pm 1^{\circ} \mathrm{C}$ for at least $30 \mathrm{~min}$. Slices were then transferred to the recording chamber that was maintained at $30 \pm 1{ }^{\circ} \mathrm{C}$, and $95 \% \mathrm{O}_{2} / 5 \% \mathrm{CO}_{2}$ bubbled continuously during dissection, incubation, and recording. A concentric bipolar stimulating electrode was placed in the Schaffer collateral pathway of $\mathrm{Crbn}{ }^{\mathrm{WT}}$ and $\mathrm{Crbn}{ }^{\mathrm{KO}}$ hippocampal slices to evoke synaptic responses, and extracellular field EPSPs were recorded in the striatum radiatum of CA1 with a glass $\mathrm{Ag} / \mathrm{AgCl}$ electrode filled with aCSF. A baseline stimulus-response curve was constructed by recording fEPSPs after stimulating the slice with increasing voltages. LTP was induced by two high-frequency stimulation trains $(100 \mathrm{~Hz}, 1 \mathrm{~s}$ duration) separated by a 20 s intertrain interval. Data acquisition and analysis were performed using Calmpex and Calmpfit 8.2 software (Molecular Devices).

Hippocampal primary neuronal cultures. Hippocampal neurons from postnatal day 0 ( $\mathrm{P} 0)-\mathrm{P} 1$ pups were generated as described previously (Beaudoin et al., 2012). Briefly, hippocampi from P0-P1 pups from Crbn wild-type or knock-out mice were dissociated in $0.05 \%$ trypsin and plated on poly-L-lysine-coated six-well plates (Costar, catalog \#3516) in Neurobasal medium containing B27 (Invitrogen, catalog \#17504044). Cultures were transfected with human CRBN (NM_016302.2) subcloned into the perceiver-M06 expression vector (GeneCopoeia) containing a hemaglutinin (HA) epitope tag (Higgins et al., 2010) using Lipofectamine 2000 (Invitrogen, catalog \#11668019) at day in vitro (DIV) 4 and used for experiments on DIV 14. Lysates were collected and processed for PSD fractions. Expression of CRBN was confirmed by detection of HA using Western blots (data not shown).

Chemical LTP induction protocol. Chemical LTP (cLTP) induction was performed as published previously (Diering et al., 2014). Briefly, hippocampal cultured neurons were preincubated for $15 \mathrm{~min}$ in cLTP buffer (125 mм NaCl, $2.5 \mathrm{~mm} \mathrm{KCl,} 2 \mathrm{~mm} \mathrm{CaCl}$, 1 mм MgCl2, 33 mm glucose, $25 \mathrm{~mm}$ HEPES, pH 7.4, $20 \mathrm{~mm}$ bicuculline, $500 \mathrm{~nm}$ TTX, and $1 \mathrm{~mm}$ strychnine) before 5 min cLTP induction in magnesium-free cLTP buffer supplemented with $200 \mu \mathrm{M}$ glycine. Neurons were allowed to recover in cLTP buffer without glycine for $15 \mathrm{~min}$ before harvesting in lysis buffer ( $1 \times$ PBS, 1 mm EDTA, 1 mm EGTA, 1\% Triton X-100 supplemented with protease and phosphatase inhibitors).

PSD preparation from primary hippocampal cultures. Postsynaptic density fractions were generated as described previously (Hussain et al., 2014). Cultured hippocampal neurons were harvested and homogenized in lysis buffer (320 mm sucrose, $10 \mathrm{~mm}$ HEPES, pH 7.4, 5 mm sodium 
Table 1. List of antibodies used for the immunoblots

\begin{tabular}{|c|c|c|c|c|c|}
\hline Protein & Company/reference & Catalog number & RRID & Antibody concentration & Molecular weight $(\mathrm{kDa})$ \\
\hline p-AMPK T72 & Cell Signaling Technology & $2535 s$ & 331250 & $1: 1000$ & 62 \\
\hline AMPK & Cell Signaling Technology & $2532 s$ & 330331 & $1: 1000$ & 62 \\
\hline mTOR & Cell Signaling Technology & 2972 & 330978 & 1:1000 & 250 \\
\hline S6 & Cell Signaling Technology & 2217 & 331355 & $1: 1000$ & 32 \\
\hline p-S6S235/236 & Cell Signaling Technology & 2211 & 331679 & $1: 1000$ & 32 \\
\hline 4EBP1 & Cell Signaling Technology & 9452 & 331692 & 1:1000 & $15-20$ \\
\hline p-eEF2 Thr56 & Cell Signaling Technology & 2331 & 2277755 & $1: 1000$ & 95 \\
\hline ATG5 & Cell Signaling Technology & 12994 & & $1: 1000$ & 55 \\
\hline ATG12 & Cell Signaling Technology & 4180 & 1903898 & $1: 1000$ & 55 \\
\hline CAMKII pan & Cell Signaling Technology & 3362 & 2067938 & 1:1000 & 50,60 \\
\hline GluA1 & Millipore & Ab1504 & 2113602 & 1:1000 & 100 \\
\hline GluA2 & Millipore & Mab397 & 2113875 & $1: 1000$ & 100 \\
\hline Synaptophysin & Abcam & Ab23754 & 778203 & $1: 1000$ & 38 \\
\hline VGLUT1 & NeuroMab & $75-066$ & 2187693 & $1: 1000$ & 52 \\
\hline VGLUT2 & NeuroMab & $75-067$ & 2239153 & $1: 1000$ & 60 \\
\hline VGAT & Synaptic Systems & 131002 & 887871 & $1: 1000$ & 55 \\
\hline GAPDH & Abcam & Ab22555 & 447153 & $1: 10,000$ & 36 \\
\hline
\end{tabular}

pyrophosphate, $1 \mathrm{~mm}$ EDTA, protease inhibitor cocktail; Sigma) using a 26.5 gauge needle. Homogenate was centrifuged at $800 \times g$ for $10 \mathrm{~min}$, resulting in $\mathrm{P} 1$ and $\mathrm{S} 1$ fractions. S1 was centrifuged at $17,000 \times g$ for 20 min to yield P2 and S2 fractions. P2 was resuspended in 4 mM HEPES, $\mathrm{pH}$ 7.4 , followed by $30 \mathrm{~min}$ mixing at $4^{\circ} \mathrm{C}$ on a nutator. The lysed $\mathrm{P} 2$ fraction was collected by centrifugation at $12,000 \times g$ for $20 \mathrm{~min}$. The resulting pellet was resuspended in $50 \mathrm{~mm}$ HEPES, pH 7.4, and an equal volume of $1 \%$ Triton X-100 and incubated on a nutator for $10 \mathrm{~min}$. PSD fractions were obtained by centrifugation at $12,000 \times g$ for $20 \mathrm{~min}$.

Subcellular fractionation of hippocampal tissue. Bilateral hippocampi were dissected and homogenized in $0.5 \mathrm{ml}$ sucrose buffer $(0.3 \mathrm{M}$ sucrose/ $0.01 \mathrm{~mm}$ HEPES) containing protease and phosphatase inhibitors. Subcellular fractionation was performed as described previously (Knackstedt et al., 2010). Homogenized lysates were spun at $1000 \times g$ for $10 \mathrm{~min}$ at $4^{\circ} \mathrm{C}$. The supernatant was collected, and the pellet was resuspended in sucrose buffer and spun at $1000 \times g$ for $10 \mathrm{~min}$. The combined supernatants were spun at $1000 \times g$ for $6 \mathrm{~min}$, and the supernatant was collected and spun at $12,000 \times \mathrm{g}$ for $20 \mathrm{~min}$. The supernatant was saved as the cytoplasmic fraction, and the pellet was resuspended in $100 \mu \mathrm{l} \mathrm{HEPES/}$ EDTA buffer (4 mM HEPES, 1 mm EDTA buffer, $\mathrm{pH}$ 7.4) and spun at $12,000 \times g$ for $20 \mathrm{~min}$. The supernatant was discarded and the pellet was resuspended in $100 \mu \mathrm{l}$ HEPES/EDTA buffer (4 mM HEPES, 1 mM EDTA buffer, $\mathrm{pH} 7.4$ ), and an aliquot was saved as the synaptosomal fraction before being spun at $12,000 \times g$ for $20 \mathrm{~min}$. The supernatant was discarded and the pellet was resuspended in $100 \mu \mathrm{l} \mathrm{G-actin}$ buffer $(4 \mathrm{~mm}$ HEPES, $100 \mathrm{~mm} \mathrm{NaCl}, \mathrm{pH}$ 7.2). Samples were spun at $12,000 \times g$ for 20 $\mathrm{min}$. The supernatant was collected and spun at $12,000 \times \mathrm{g}$ for $20 \mathrm{~min}$, and the pellet was resuspended in $100 \mu \mathrm{l}$ of F-actin buffer ( 4 mM HEPES, $150 \mathrm{~mm} \mathrm{NaCl}, \mathrm{pH} 7.5$ ) and was placed on a nutator at $4^{\circ} \mathrm{C}$ for $1 \mathrm{~h}$. Samples were spun at $10,000 \times g$ for $15 \mathrm{~min}$, and the supernatant was collected and spun again at $1000 \times g$ for $5 \mathrm{~min}$. The supernatant was collected and saved as the Triton-insoluble PSD protein fraction.

Western blot analysis. Gel electrophoresis of 10-20 $\mu \mathrm{g}$ of protein was performed on a $10 \%$ SDS-polyacrylamide gel. The protein was transferred to PVDF membrane. Blots were probed with IgG anti-rabbit or anti-mouse primary antibodies (Table 1 ) overnight on a rotator at $4^{\circ} \mathrm{C}$, and were then incubated with goat anti-rabbit or horse anti-mouse peroxidase-labeled IgG for $1 \mathrm{~h}$ on a rotator at room temperature. Protein bands were visualized using chemiluminescence (PerkinElmer). Precision Plus Protein Dual Color Standards (Bio-Rad) were used for protein size determination. For quantification, samples were normalized to GAPDH as a loading control. Intensity of the protein bands was measured using ImageJ software (NIH).

Quantitative real-time PCR. RNA was isolated from unilateral hippocampus using the RNeasy Mini Kit and reagents (Qiagen). cDNA was synthesized from purified RNA, using the High-Capacity RNA-to-cDNA Kit (Applied Biosystems), and quantified by qRT-PCR using mRNAspecific primers (CaMK2a, QT00129164; Gria1, QT01062544; Gria2, QT00140000; Grin1, QT01751477; Grin2a, QT00093562; Grin2b, QT00169281; Qiagen) on an ABI PRISM 7000 Sequence Detection System with SYBRGreen PCR Master Mix (Applied Biosystems). Amplification was performed for $40 \mathrm{cycles}\left(95^{\circ} \mathrm{C}\right.$ for $15 \mathrm{~s} ; 60^{\circ} \mathrm{C}$ for $30 \mathrm{~s} ; 72^{\circ} \mathrm{C}$ for $30 \mathrm{~s}$; extension, $72^{\circ} \mathrm{C}$ for $\left.10 \mathrm{~min}\right)$. Each reaction was performed in triplicate, and values were averaged. Threshold (Ct) values were normalized to mouse Gapdh using the following formula: $\Delta \mathrm{Ct}=\mathrm{Ct}$ (gene) $-\mathrm{Ct}($ Gapdh). The $\Delta \mathrm{Ct}$ method was used to assess the relative mRNA expression. Expression levels were calculated relative to controls using the following formula: $\Delta \Delta \mathrm{Ct}=\Delta \mathrm{Ct}$ (treated) $-\Delta \mathrm{Ct}$ (control). The final expression levels were obtained using the formula $2^{(-\Delta \Delta \mathrm{CT})}$.

Statistics. Behavioral and molecular data were analyzed by two-way ANOVA or independent samples $t$ test. Data that showed a significant interaction by two-way ANOVA were subsequently analyzed by Bonferroni post hoc analysis. LTP data were analyzed using a linear regression and independent samples $t$ test. All statistical analyses were performed using Prism 6 (GraphPad) software.

\section{Results}

\section{Cereblon is highly expressed in the mouse hippocampus}

As the hippocampus is critically involved in learning and memory formation, we performed Western blot analysis using hippocampal protein lysates from $C r b n^{\mathrm{WT}}$ and $\mathrm{Crbn}{ }^{\mathrm{KO}}$ mice (Fig. 1A). As expected, Crbn protein was detected at $51 \mathrm{kDa}$ in $\mathrm{Crbn}{ }^{\mathrm{WT}}$ mice, with the band absent in $\mathrm{Crbn}{ }^{\mathrm{KO}}$ mice. Immunohistochemical staining of $\mathrm{Crbn}{ }^{\mathrm{WT}}$ and $\mathrm{Crbn} n^{\mathrm{KO}}$ hippocampus using antibodies to $\mathrm{NeuN}$, a neuronal marker, revealed that $\mathrm{Crbn}{ }^{\mathrm{KO}}$ brains have normal gross morphology at postnatal week 8 (Fig. 1B). Lowmagnification analysis indicated that Crbn is expressed in all hippocampal circuits, including the CA1 neurons and the stratum 


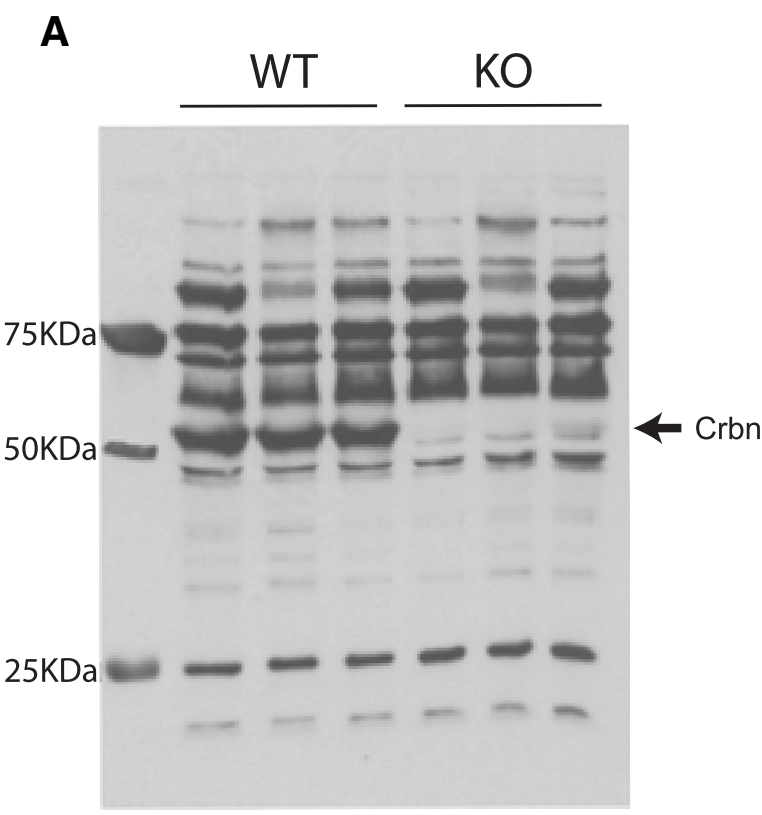

B
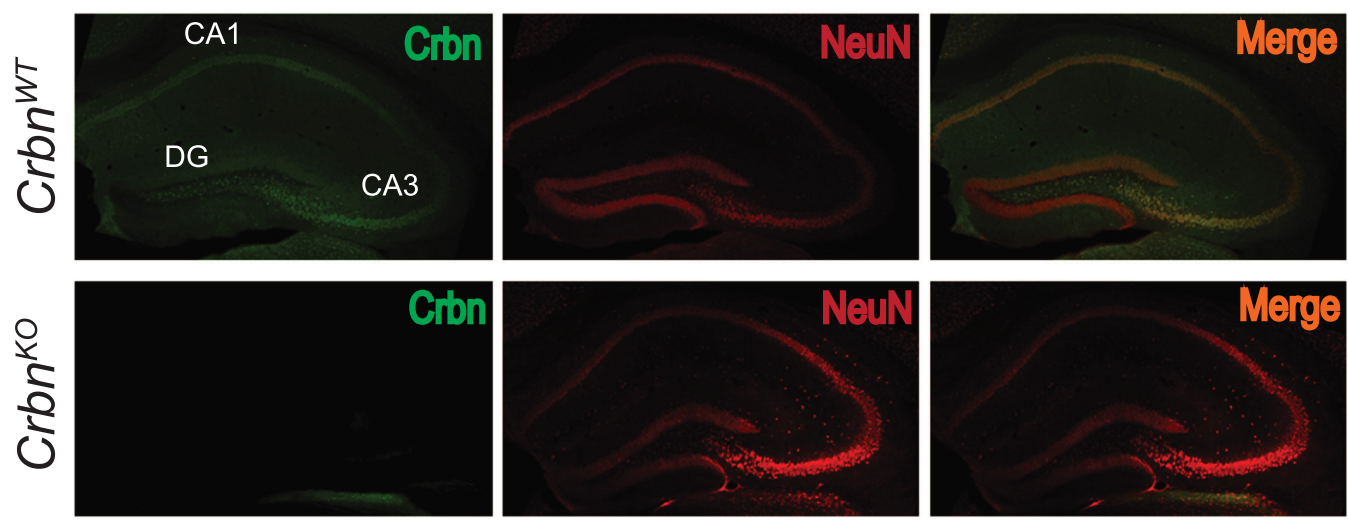

Figure 1. Validation of cereblon antibody by Western blot analysis and immunohistochemistry. A, Western blot with total hippocampal protein lysates from $\mathrm{Crbn}^{\mathrm{WT}}$ and $\mathrm{Crbn}^{\mathrm{K} 0}$ mice. A band at the expected $51 \mathrm{KDa}$ size present in $\mathrm{Crbn}^{\mathrm{WT}}$ mice but absent in $\mathrm{Crbn}^{K O}$ mice confirms the specificity of the antibody. $\boldsymbol{B}$, Representative images of hippocampal sections stained for NeuN (left) and cereblon (middle). Cereblon staining is visible in all subregions of the $\mathrm{Crbn}^{\mathrm{WT}}$ but not the $\mathrm{Crbn}^{\mathrm{KO}}$ hippocampus.

radiatum containing the CA3 projections (Schaffer collaterals) to CA1 neurons (Fig. 1B).

\section{Loss of cereblon results in learning and memory deficits}

To test the role of Crbn in hippocampal-based learning and memory, we used the MWM test and the water-based Y-maze test. In the MWM, mice were trained to locate a submerged platform with the help of extramaze cues. $\mathrm{Crbn}{ }^{\mathrm{KO}}$ mice took significantly longer to locate the submerged platform than did Crbn WT mice during training (Fig. $2 A$; main effect of genotype, $F_{(1,18)}=$ 10.53, $p=0.005$; main effect of day, $F_{(3,54)}=3.37, p=0.02$; two-way repeated measures ANOVA), indicating a deficit in learning in $\mathrm{Crbn}{ }^{\mathrm{KO}}$ mice. Long-term memory was assessed $48 \mathrm{~h}$ following the final training session, and $C r b n^{\mathrm{WT}}$ mice spent significantly more time in the goal zone compared to the other two zones (Fig. $2 B$; main effect of zone, $F_{(2,27)}=13.26, p<0.0001$; one-way ANOVA), while $\mathrm{Crbn}^{\mathrm{KO}}$ mice did not (Fig. $2 B$ ).

In the water-based Y-maze task, mice were trained to locate a submerged platform in one of three arms of the Y-maze apparatus, and latency to locate the platform was recorded. During training, $\mathrm{Crbn}{ }^{\mathrm{KO}}$ mice took significantly longer to locate the platform compared to $C r b n^{\text {WT }}$ mice (Fig. $2 C$; main effect of genotype, $F_{(1,12)}=8.50, p=0.01$; main effect of day, $F_{(6,72)}=3.00$, $p=0.01$; two-way repeated measures ANOVA). Long-term memory was then assessed $24 \mathrm{~h}$ following the last training trial. During the memory test, $\mathrm{Crbn}{ }^{\mathrm{KO}}$ mice took significantly longer to locate the platform than did Crbn ${ }^{\mathrm{WT}}$ mice (Fig. $2 D ; t_{(14)}=$ $2.35, p=0.03$, independent-samples $t$ test), indicating a deficit in memory in $\mathrm{Crbn}^{\mathrm{KO}}$ mice.

To examine the role of Crbn in working memory, we chose the spontaneous alternation task (Wietrzych et al., 2005). No difference in percentage of spontaneous alternations between $\mathrm{Crbn}{ }^{\mathrm{KO}}$ and $C r b n^{\text {WT }}$ mice was observed (Fig. 2E). The above results demonstrate that Crbn is necessary for hippocampal learning and memory but not for working memory.

Loss of cereblon has no effect on social or repetitive behavior As CRBN has been linked to ASDs (Pinto et al., 2010), we next examined whether loss of Crbn alters social behavior, a core symp- 

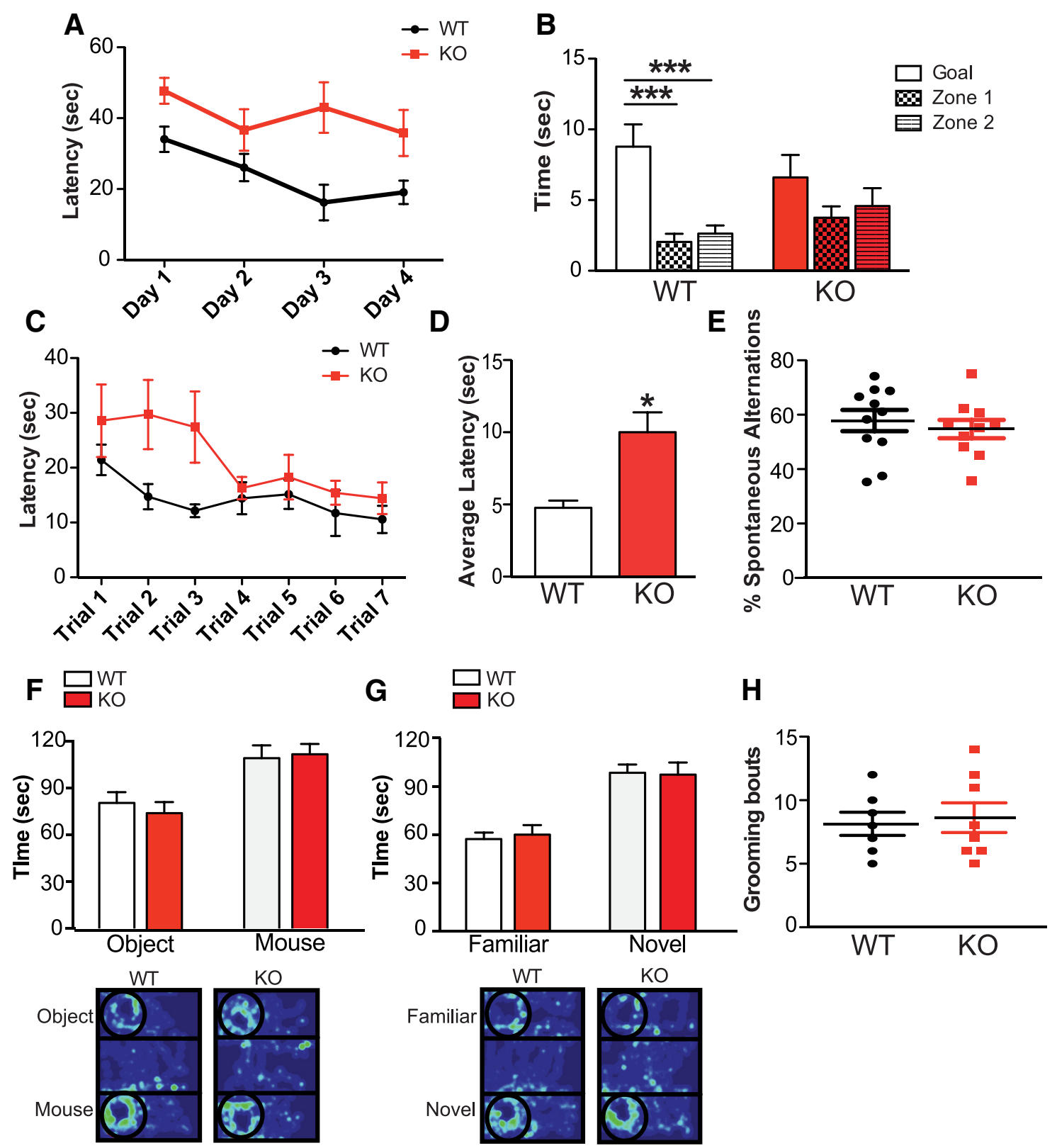

Figure 2. $\quad \mathrm{Crbn}^{\mathrm{K} 0}$ mice demonstrate learning and memory deficits in the Morris water maze and water-based Y-maze tests, with no deficits in a working memory test. $\boldsymbol{A}$, In the MWM training, $\mathrm{Crbn}^{\mathrm{K} 0}$ mice displayed increased latency to find a hidden platform compared to $\mathrm{Crbn}{ }^{\mathrm{WT}}$ mice ( $n=10 /$ genotype). $\boldsymbol{B}$, In the MWM probe test, ${ }^{2}$ rbn ${ }^{\mathrm{WT}}$ mice spent significantly more time in the goal zone compared to either zone 1 or zone 2, whereas $C r b n^{K 0}$ mice did not. ${ }^{* * *} p<0.001$ ( $n=10 /$ genotype). $C$, In the Y-maze training, $\mathrm{Crbn}^{\mathrm{K} 0}$ mice demonstrated increased latency to find the hidden platform compared to $\mathrm{Crbn}{ }^{\mathrm{WT}}$ mice ( $n=7 /$ genotype). D, During the Y-maze probe test, $\mathrm{Crbn}{ }^{\mathrm{K} 0}$ mice took longer to locate the submerged platform compared to $\mathrm{Crbn}{ }^{\mathrm{WT}}$ mice. ${ }^{*} p<0.05(n=$ 7/genotype). $\boldsymbol{E}$, $\mathrm{Crbn}{ }^{\mathrm{K} 0}$ mice did not show impaired working memory in the spontaneous alternation task compared to $\mathrm{Crbn}^{\mathrm{WT}}$ mice (Crbn $\left.{ }^{\mathrm{WT}}, n=11 ; \mathrm{Crbn}^{\mathrm{KO}}, n=10\right) . \boldsymbol{F}$, In the social interaction

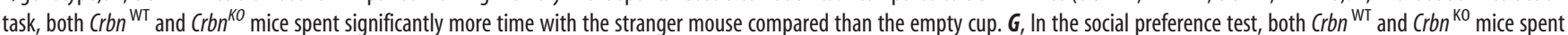
significantly more time with the novel stranger mouse than the familiar mouse. $\boldsymbol{H},\left(\mathrm{Crbn}{ }^{\mathrm{WT}}\right.$ and $\mathrm{Crbn}^{\mathrm{K} 0}$ mice showed no differences in repetitive grooming behavior (Crbn $\left.{ }^{\mathrm{WT}}, n=7 ; \mathrm{Crbn}{ }^{\mathrm{K} 0}, n=8\right)$. Data are displayed as mean \pm SEM.

tom of ASDs. We conducted the three-chamber social interaction and social preference tests (Silverman et al., 2010). Examination of basal locomotion revealed no difference in locomotor activity between $\mathrm{Crbn}^{\mathrm{WT}}$ and $\mathrm{Crbn}{ }^{\mathrm{KO}}$ mice $\left(\mathrm{Crbn}{ }^{\mathrm{WT}}, n=6\right.$, $9030 \pm 580.4 \mathrm{~cm}$ vs $C r b n^{\mathrm{KO}}, n=6,10845 \pm 878.5 \mathrm{~cm} ; t_{(10)}=1.72$, independent samples $t$ test). During the social interaction task, in which sociability was defined as time spent interacting with a novel conspecific mouse versus a novel object, both $C r b n^{\mathrm{KO}}$ and $\mathrm{Crbn}^{\text {WT }}$ mice spent significantly more time with the stranger mouse than with the object (Fig. 2F; main effect of contact zone, $F_{(1,40)}=20.8, p<0.0001$, two-way ANOVA), indicating normal sociability. Additionally, in the social preference task, in which sociability was defined as the time spent interacting with a new stranger mouse versus a familiar mouse, both $\mathrm{Crbn}{ }^{\mathrm{KO}}$ and $\mathrm{Crbn}{ }^{\mathrm{WT}}$ mice spent more time with the stranger mouse than the familiar mouse (Fig. 2G; main effect of contact zone, $F_{(1,40)}=23.2, p<$ 0.0001, two-way ANOVA). These results indicate that loss of Crbn has no effect on social behavior.

Repetitive behaviors are another core symptom of ASDs, and thus, we next determined whether loss of Crbn alters repetitive grooming behavior. No difference in repetitive grooming behavior was found between $\mathrm{Crbn}^{\mathrm{KO}}$ and $\mathrm{Crbn}{ }^{\mathrm{WT}}$ mice (Fig. $2 \mathrm{H}$ ), indicating 
A

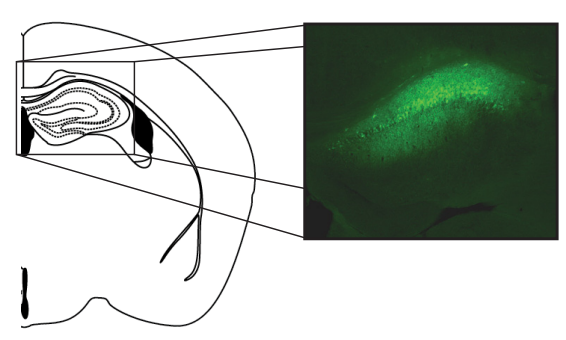

C

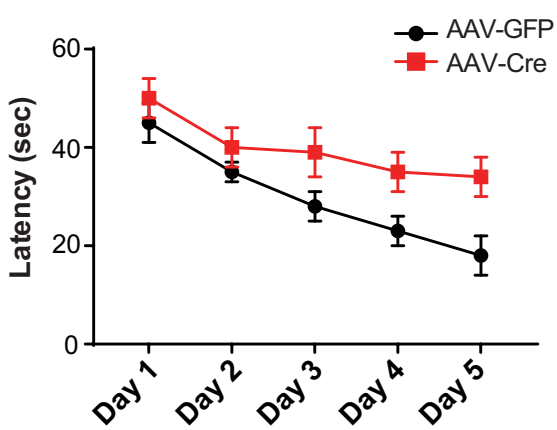

E

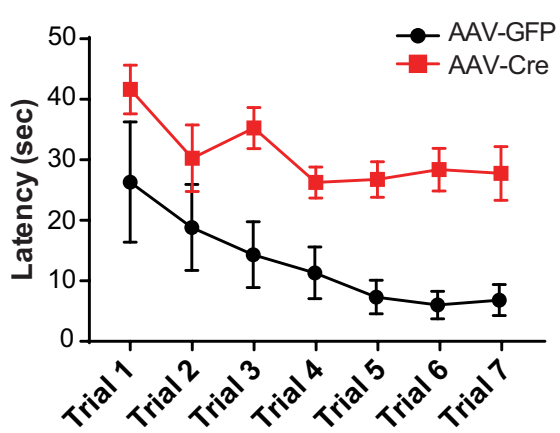

B

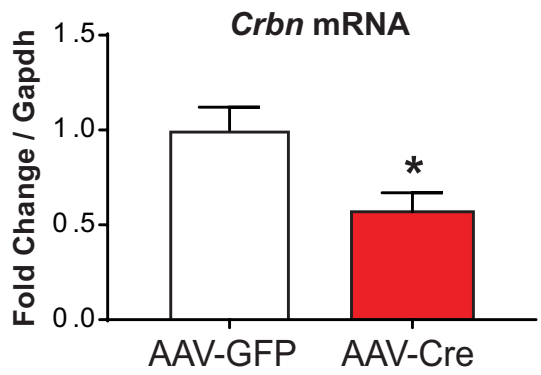

D

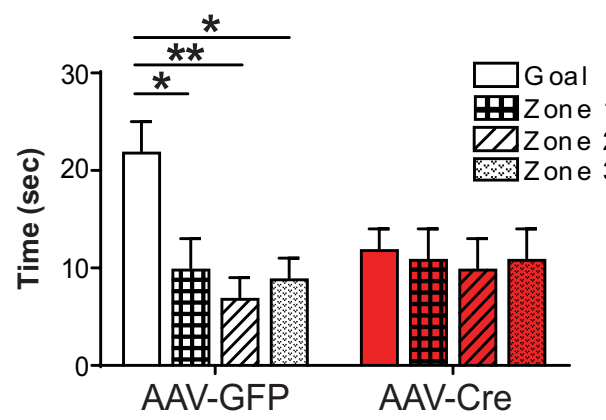

$F$

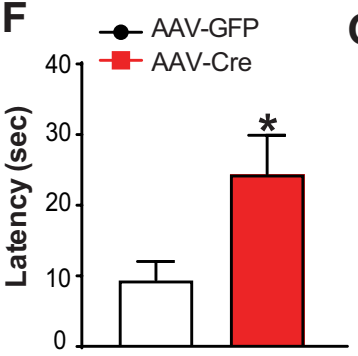

Figure 3. Focal knockdown of CRBN in the dorsal hippocampus induced deficits in learning and memory. $A$, Representative image of GFP expressed by microinjection of AAV-Cre into the dorsal hippocampus of $C R B N^{f l / f l}$ mice. $B$, Injection of AAV-Cre into the dorsal hippocampus of $C R B N^{f l / f l}$ mice resulted in a significant decrease in Crbn mRNA expression in the dorsal hippocampus compared to injection of AAV-GFP (AAV-GFP, $n=6$; AAV-Cre, $n=8$ ). $C$, In the MWM training, knockdown of CRBN in the dorsal hippocampus increased latency to find a hidden platform during $5 \mathrm{~d}$ of training (AAV-GFP, $n=6$; AAV-Cre, $n=8$ ). $\boldsymbol{D}$, In the MWM probe test, mice injected with AAV-GFP spent significantly more time in the goal zone compared to zone 1 , zone 2, or zone 3 (AAV-GFP, $n=6$; AAV-Cre, $n=8$ ), while mice injected with AAV-Cre did not. $\boldsymbol{E}$, During the Y-maze training, mice injected with AAV-Cre displayed increased latency to find a hidden platform compared to mice injected with AAV-GFP (AAV-GFP, $n=6 ; A A V-C r e, n=8$ ). $F$, During the $y$-maze probe test, mice injected with AAV-Cre demonstrated increased latency to find the hidden platform compared to mice injected with AAV-GFP ( ${ }^{*} p<0.05 ; A A V-G F P, n=6$; AAV-Cre, $\left.n=8\right)$. G, In a test of contextual fear conditioning, mice injected with AAV-Cre spent a significantly lower percentage of time freezing compared to mice injected with AAV-GFP (AAV-GFP, $n=6 ;$ AAV-Cre, $n=8)$. ${ }^{*} p<0.05 ;{ }^{* *} p<0.01$ (Bonferroni post hoc). Data are displayed as mean \pm SEM.

that the $\mathrm{Crbn}{ }^{\mathrm{KO}}$ mouse lacks typical ASD-like phenotypes as measured in mouse models.

\section{Loss of Crbn within the dorsal hippocampus results in learning and memory deficits}

As we saw deficits in hippocampal-dependent learning and memory tasks in $\mathrm{Crbn}{ }^{\mathrm{KO}}$ mice, we next tested the role of Crbn within the dorsal hippocampus in these behavioral tasks. We generated mice with a focal knockdown of Crbn primarily within the CA1 subregion within the dorsal hippocampus by stereotaxic microinjection of AAV-Cre into bilateral dorsal hippocampus of Crbnfloxed mice (Fig. 3A). This resulted in significantly lower levels of Crbn mRNA compared to control AAV-GFP-injected mice (Fig. $3 B ; t_{(12)}=2.77, p=0.02$, independent samples $t$ test). Deletion of
Crbn in the dorsal hippocampus significantly impaired learning in the MWM; mice injected with AAV-Cre took significantly longer to locate the hidden platform compared to control mice injected with AAV-GFP (Fig. $3 C$; main effect of day, $F_{(4,60)}=$ 8.76, $p<0.0001$; main effect of treatment, $F_{(1,60)}=14.96, p=$ 0.0003; two-way ANOVA). Additionally, deletion of Crbn in the dorsal hippocampus impaired memory in the MWM probe test, as AAV-GFP mice spent significantly more time in the goal zone compared to the other zones (Fig. 3D; main effect of zone, $F_{(3,20)}=$ 7.077, $p=0.002$, one-way ANOVA) while AAV-Cre mice did not (Fig. 3D).

Similarly, deletion of $\mathrm{Crbn}$ in the dorsal hippocampus significantly increased latency to find the hidden platform during Y-maze training (Fig. $3 E$; main effect of trial, $F_{(6,84)}=3.68, p=$ 0.003; main effect of treatment, $F_{(1,84)}=52.06, p<0.0001$; two- 

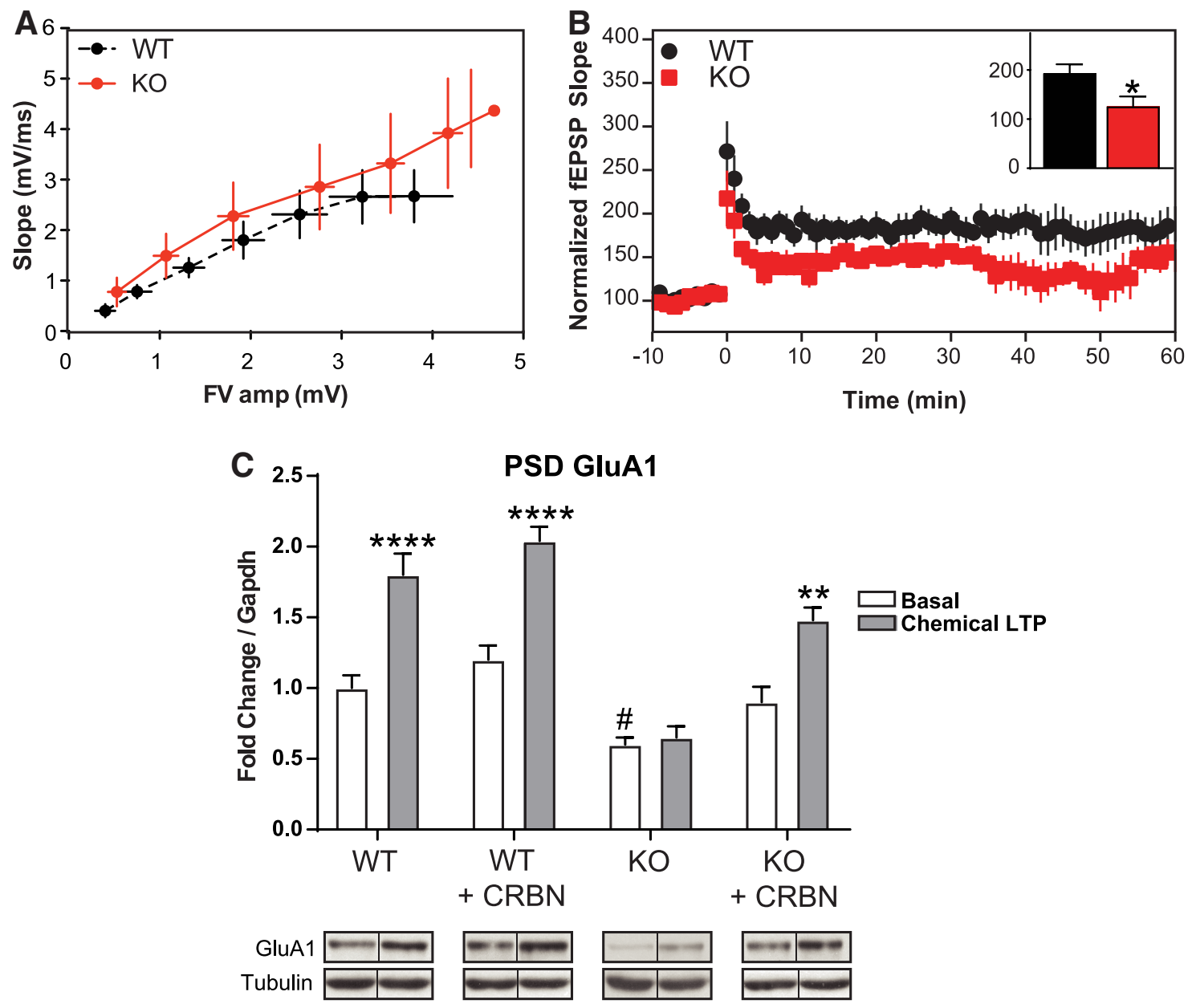

Figure 4. $\quad \mathrm{Cr} b n^{\mathrm{K} 0}$ mice have impairments in long-term potentiation and synaptic plasticity. $\boldsymbol{A}$, Input/output curves expressed as EPSP slopes (in millivolts per millisecond) plotted against stimulus intensity (in millivolts). No differences between genotypes were found ( $n=5 /$ genotype). $\boldsymbol{B}$, LTP represented as the normalized fEPSP slope over the course of $60 \mathrm{~min}$. Crbn ${ }^{\mathrm{K} 0} \mathrm{mice}$ showed a significant deficit in LTP during the first 40 min compared to $C r b n{ }^{W T}$ mice ( $n=5 /$ genotype). $C$, $\left(r b n{ }^{\mathrm{KO}}\right.$ mice displayed a deficit in chemical LTP-induced increase in GluA1 protein levels in the PSD, which was rescued by overexpression of human CRBN ( $n=5 /$ genotype). ${ }^{\#} p<0.05$ (Bonferroni post hoc test, WT basal vs KO basal); ${ }^{*} p<0.05 ;{ }^{* *} p<0.01,{ }^{* * * *} p<0.0001$ (Bonferroni post hoc test, basal vs chemical LTP). Data displayed as mean \pm SEM.

way ANOVA) and $24 \mathrm{~h}$ probe test (Fig. $3 F ; t_{(12)}=2.22, p=0.04$, independent samples $t$ test).

We previously showed that $\mathrm{Crbn}{ }^{\mathrm{KO}}$ mice demonstrate a memory deficit in contextual fear conditioning (Rajadhyaksha et al., 2012), so we next tested the role of dorsal hippocampus Crbn on contextual fear memory. Mice were trained to associate a conditioned stimulus, a novel context, with an unconditioned stimulus, a foot shock. During a $24 \mathrm{~h}$ contextual fear conditioning test, mice were placed back into the context and freezing was recorded. Deletion of Crbn in the dorsal hippocampus significantly reduced the percentage of time freezing (Fig. $3 G ; t_{(12)}=3.65, p=$ $0.003)$, indicative of a memory deficit.

\section{$C r b n^{\mathrm{KO}}$ mice demonstrate deficits in hippocampal long-term potentiation}

Hippocampal LTP at the Schaffer collateral to CA1 pathway is a commonly used synaptic model of learning and memory (Malenka, 2003). Given our finding that Crbn is required for hippocampal learning and memory, we sought to investigate the role of Crbn in the induction of LTP in the hippocampus. To measure a baseline stimulus-response curve, fEPSPs were recorded in the striatum radiatum of CA1 following stimulation of the Schaffer collateral pathway at varying intensities $(0-4 \mathrm{mV})$. No differences in base- line input/output curves were found between $\mathrm{Crbn} n^{\mathrm{KO}}$ and $\mathrm{Crbn}{ }^{\mathrm{WT}}$ mice at any intensity (Fig. 4A). LTP was induced by two $100 \mathrm{~Hz}$ stimulation trains ( $1 \mathrm{~s}$ duration, $20 \mathrm{~s}$ interval), and fEPSPs were recorded for $60 \mathrm{~min}$. LTP was quantified as the fEPSP slope as a percentage of baseline (Fig. $4 B$ ), and $\mathrm{Crbn}^{\mathrm{KO}}$ mice displayed a significant deficit in LTP compared to Crbn ${ }^{\mathrm{WT}}$ mice (Fig. $4 B ; t_{(13)}=$ $2.49, p=0.03$, independent samples $t$ test). We confirmed these findings using cLTP in hippocampal cultures from $\mathrm{Crbn}{ }^{\mathrm{WT}}$ and $\mathrm{Crbn}^{\mathrm{KO}}$ mice (Fig. $4 C$ ). We induced cLTP using a standard protocol (Diering et al., 2014) in which cells were incubated with glycine to selectively activate synaptic NMDA receptors and induce insertion of AMPA receptors into synapses. We found that cLTP induced a significant increase in PSD expression of GluA1 in Crbn ${ }^{\mathrm{WT}}$ mice but not in Crbn ${ }^{\mathrm{KO}}$ mice, and that this deficit in cLTP could be rescued by overexpression of Crbn (Fig. $4 C$; significant interaction of group $\times \operatorname{cLTP}, F_{(3,32)}=6.63, p=0.001$, two-way ANOVA).

\section{$C r b n^{\mathrm{KO}}$ mice exhibit exaggerated levels of activated AMPK $\alpha$} in the hippocampus

Of the Crbn targets that have been identified (Lee et al., 2014), AMPK serves as an intriguing target in the hippocampus given its link to multiple downstream pathways (Horman et al., 2002; 
A

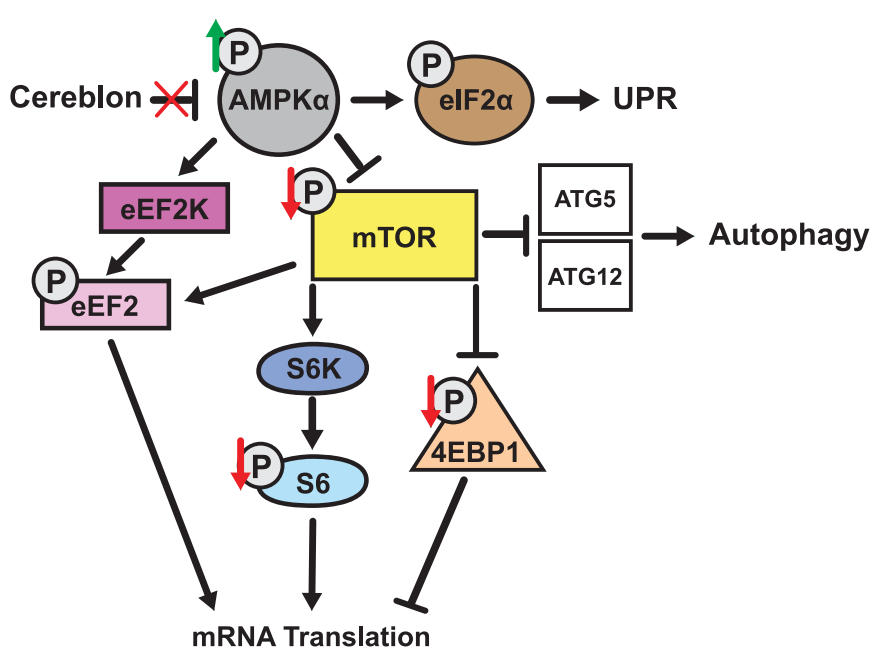

B

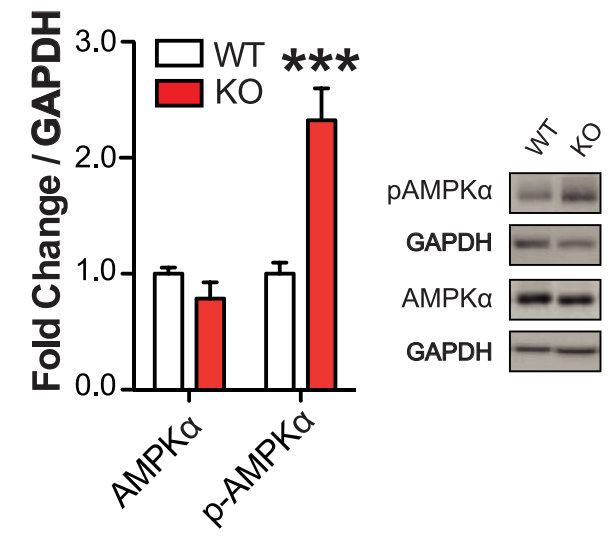

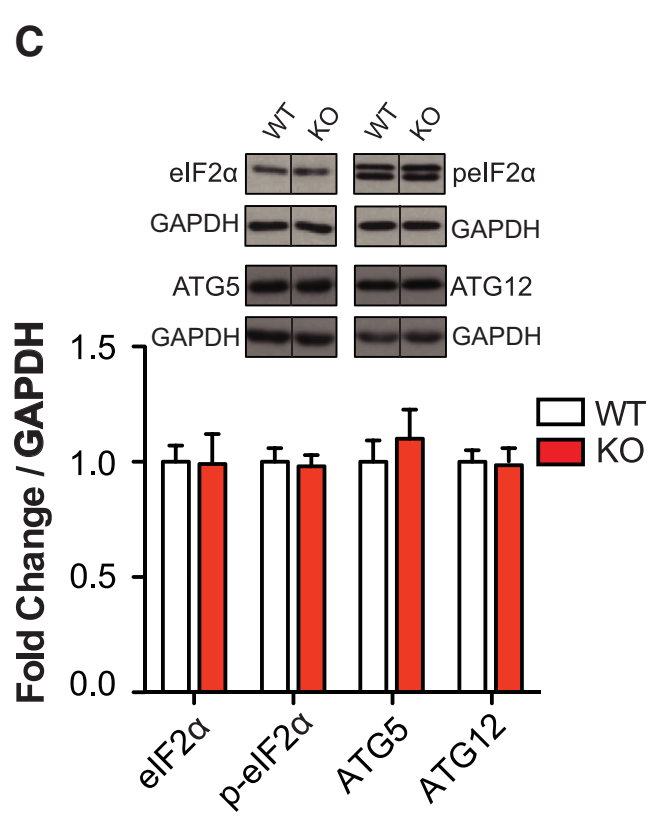
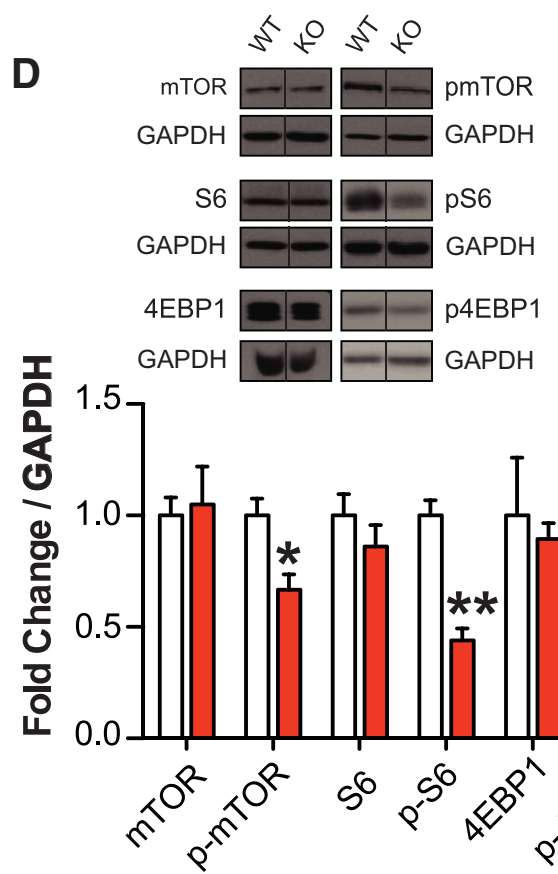

Figure 5. C $C r b n^{\mathrm{KO}}$ mice show altered mTORC1 signaling in the hippocampus. A, Schematic of proposed molecular mechanism. B, Compared to Crbn ${ }^{\mathrm{WT}}$ mice, $C r b n^{\mathrm{KO}}$ mice displayed significantly higher synaptosomal levels of phosphorylated AMPK $\alpha$ (Thr172) in the hippocampus ( $\left(r b n{ }^{W T}, n=10 ; C_{r b}{ }^{\mathrm{K} 0}, n=14\right)$, with no difference found in levels of total AMPK $\alpha\left(C r b n{ }^{\mathrm{WT}}, n=6 ; \mathrm{Crbn}{ }^{\mathrm{KO}}\right.$, $n=7)$. C, Crbn ${ }^{\text {WT }}$ and Crbn ${ }^{\mathrm{KO}}$ mice displayed similar levels of synaptosomal elF2 $\alpha$ and phosphorylated elF2 $\alpha$ well as cytoplasmic ATG5 and ATG12 in the hippocampus ( $n=5 / g$ enotype). D, (rbn ${ }^{\mathrm{KO}}$

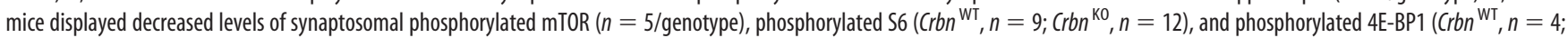

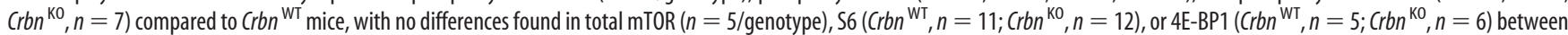
$\mathrm{Crbn}^{\mathrm{WT}}$ and $\mathrm{Crbn}{ }^{\mathrm{K} 0}$ mice. $\mathrm{Crbn}^{\mathrm{WT}}$ and $\mathrm{Cr} b n^{\mathrm{K} 0}$ mice displayed similar levels of phosphorylated eEF2 Thr56 and total eEF2 ( $n=5 /$ genotype). ${ }^{*} p<0.05 ;{ }^{* *} p<0.01 ;{ }^{* * *} p<0.001$. Data are displayed as mean \pm SEM. Western blot images are representative samples taken from the same blot.

Inoki et al., 2003; Rosso et al., 2016) and its potential to impact learning, memory, and synaptic deficits (Ma et al., 2014; Han et al., 2016) in Crbn ${ }^{\mathrm{KO}}$ mice (Fig. 5A). We first measured levels of phosphorylated AMPK $\alpha$ in hippocampal synaptosomal fractions to examine changes in AMPK $\alpha$ phosphorylation at Thr172 (pAMPK), which generates the active form of AMPK $\alpha$. Crbn ${ }^{\mathrm{KO}}$ mice had significantly higher levels of $\mathrm{p}-\mathrm{AMPK} \alpha$ compared to $\mathrm{Crbn}^{\mathrm{WT}}$ mice, with a more than twofold increase in levels, indicating robust control of AMPK $\alpha$ phosphorylation in the synaptosome by Crbn (Fig. $5 B ; t_{(22)}=3.99, p=0.0006$, independent samples $t$ test). No difference in total AMPK $\alpha$ protein level was observed (Fig. 4B), confirming AMPK $\alpha$ phosphorylation as a target of Crbn in the mouse hippocampus.
Loss of Crbn does not activate the unfolded protein response in the hippocampus

AMPK has been implicated in activation of the UPR via phosphorylation of eukaryotic initiation factor $2 \alpha$ (eIF2 $\alpha$; AppenzellerHerzog and Hall, 2012; Liu-Bryan and Terkeltaub, 2015). EIF2 $\alpha$, when phosphorylated at S51, inhibits initiation of general mRNA translation and activates UPR-specific genes (Buffington et al., 2014). UPR activation has been implicated in models of Alzheimer's disease, and inhibition of this mechanism attenuates memory deficits in these models (Ma et al., 2013). Therefore, we chose to examine whether $\mathrm{Crbn}{ }^{\mathrm{KO}}$ mice show differences in UPR. Analysis of hippocampal synaptosomal tissue revealed no differences in levels of eIF $2 \alpha$ or p-eIF $2 \alpha$ between $C r b n^{\mathrm{KO}}$ and $\mathrm{Crbn}{ }^{\mathrm{WT}}$ mice 
(Fig. 5C), indicating that loss of Crbn does not impact eIF2 $\alpha$ mediated UPR downstream of AMPK.

\section{Loss of Crbn does not induce activation of autophagy in the hippocampus}

AMPK, via inhibiting mTORC1, is well known for activating autophagy (Nixon, 2006; Picard et al., 2016), a mechanism linked to memory deficits (Hegde, 2017), including those seen in neurodegenerative disorders such as Alzheimer's disease (Kiriyama and Nochi, 2015). Autophagy has also been shown to regulate spine pruning associated with cognitive deficits (Tang et al., 2014; Kim et al., 2017). Thus, we next examined levels of the autophagy markers ATG5 and ATG12, which form a complex necessary for formation of the autophagasome and promotion of autophagy (Walczak and Martens, 2013). Within cytoplasmic fractions of the hippocampus, we observed no differences in ATG5 protein levels or ATG12 levels at the $55 \mathrm{kDa}$ band, which quantifies levels of ATG12 bound to ATG5, between $\mathrm{Crbn}{ }^{\mathrm{KO}}$ and $\mathrm{Crbn}{ }^{\mathrm{WT}}$ mice (Fig. $5 C$ ), suggesting that loss of Crbn does not activate autophagy downstream of AMPK.

\section{$\mathrm{Crbn}{ }^{\mathrm{KO}}$ mice demonstrate downregulation of mTORC1 mRNA translation initiation factors in the hippocampus} AMPK regulates dendritic protein synthesis via mTORC1 (Inoki et al., 2003; Hoeffer and Klann, 2010; Rosso et al., 2016) and the eEF2 pathway (Horman et al., 2002; Hardie, 2004), both of which, via regulating initiation and elongation of mRNA translation, respectively, play a critical role in consolidating long-term synaptic plasticity and long-term memory (Graber et al., 2013; Taha et al., 2013). Heightened activity of AMPK has been shown to repress mRNA translation by inhibition of mTORC1 (Inoki et al., 2003). Similarly, upregulation of AMPK phosphorylates and thereby inhibits eEF2, also leading to a decrease in mRNA translation (Horman et al., 2002).

To examine the effect of loss of Crbn and hyperphosphorylation of AMPK on mTORC1 activity, we used Western blot analysis of synaptosomal fractions of the hippocampus. $\mathrm{Crbn}^{\mathrm{KO}}$ mice displayed significantly lower levels of phosphorylated mTOR S2448 (Fig. $5 D ; t_{(8)}=3.24, p=0.01$, independent samples $t$ test), a marker of mTORC1 activity, and its downstream mRNA initiation factors, phosphorylated S6 S235/236 (Fig. $5 D ; t_{(11)}=4.45$, $p=0.001$, independent samples $t$ test) and phosphorylated $4 \mathrm{E}$ BP1 T37/46 (Fig. $5 D ; t_{(9)}=2.53, p=0.03$ ) in the synaptosome compared to $\mathrm{Crbn}{ }^{\mathrm{WT}}$ mice. No differences in total protein levels of mTOR, S6, or 4E-BP1 were observed (Fig. 5D), indicating that downregulation of mTORC1 pathway most likely occurs through direct inhibition by AMPK (Fig. $5 \mathrm{~A}$ ). In contrast to downregulation of mTORC1-dependent initiation factors, no differences were found in the levels of the elongation factor eEF2 or phosphorylated eEF2 Thr56 between $\mathrm{Crbn}{ }^{\mathrm{WT}}$ and $\mathrm{Crbn}{ }^{\mathrm{KO}}$ mice (Fig. $5 D$ ), suggesting that loss of Crbn specifically targets mTORC1dependent initiation of mRNA translation via $\mathrm{AMPK} \alpha$.

\section{Loss of Crbn results in downregulation of excitatory postsynaptic proteins in the hippocampus}

We next examined changes in excitatory glutamatergic synaptic proteins that play a central role in LTP and learning and memory (Nicoll and Malenka, 1999; Malinow and Malenka, 2002) and are regulated by mTOR-mediated mRNA translation (Buffington et al., 2014; Leal et al., 2014; Phillips and Pozzo-Miller, 2015). For these studies, we examined synaptic protein levels using PSD fractions prepared from hippocampal tissue. $\mathrm{Crbn}{ }^{\mathrm{KO}}$ mice had lower levels of CAMKII $\alpha$ (Fig. $6 A ; t_{(21)}=2.9, p=0.009$, inde- pendent samples $t$ test), CAMKII $\beta$ (Fig. $6 A ; t_{(11)}=3.63, p=$ 0.004 , independent samples $t$ test), GluA1 (Fig. $6 A ; t_{(21)}=2.73$, $p=0.01$, independent samples $t$ test), GluA2 (Fig. $6 A ; t_{(11)}=2.5$, $p=0.03$, independent samples $t$ test), GluN1 (Fig. $6 A ; t_{(21)}=$ $3.68, p=0.0014$, independent samples $t$ test), GluN2A (Fig. 6 A $t_{(6)}=2.76, p=0.03$, independent samples $t$ test), and GluN2B (Fig. $6 A ; t_{(20)}=3.99, p=0.0007$, independent samples $t$ test) in the hippocampal PSD. Examination of hippocampal mRNA levels by qRT-PCR revealed no differences between $\mathrm{Crbn}{ }^{\mathrm{KO}}$ and $\mathrm{Crbn}{ }^{\mathrm{WT}}$ mice (Fig. $6 \mathrm{~B}$ ), suggesting that these proteins are altered at the level of mRNA translation and that Crbn deficiency results in downregulation of excitatory glutamatergic synaptic proteins.

\section{Loss of Crbn results in higher levels of markers of excitatory glutamatergic synapses}

Both AMPK and mTOR signaling are known to regulate spine number and spine density (Swiech et al., 2008; Li et al., 2010; Amato et al., 2011; Mairet-Coello et al., 2013; Han et al., 2016). Therefore, we next examined molecular markers of spines using synaptosomal fractions from the hippocampus. Surprisingly, $\mathrm{Crbn}{ }^{\mathrm{KO}}$ mice had higher levels of both postsynaptic spine marker PSD-95 (Fig. 6C; $t_{(11)}=2.62, p=0.02$, independent samples $t$ test) and the presynaptic maker synaptophysin (Fig. $6 C ; t_{(11)}=2.29, p=0.04$, independent samples $t$ test).

As an imbalance in excitatory and inhibitory synapses has been found to be disrupted in several animal models of intellectual disability (Verpelli et al., 2014; Gao and Penzes, 2015; Mullins et al., 2016), we examined protein levels of excitatory and inhibitory presynaptic markers, vesicular glutamate (VGLUT1/ VGLUT2) and GABA (VGAT) transporters, respectively, using synaptosomal fractions isolated from the hippocampus. $\mathrm{Crbn} n^{\mathrm{KO}}$ mice had higher levels of VGLUT1 (Fig. $6 C$; $t_{(12)}=3.49, p=$ 0.005 , independent samples $t$ test) and VGLUT2 (Fig. $6 C ; t_{(12)}=$ $2.86, p=0.014$, independent samples $t$ test), with no difference in VGAT levels (Fig. 6C). Furthermore, $\mathrm{Crbn}{ }^{\mathrm{KO}}$ mice showed increased ratios VGLUT1/VGAT (Fig. $6 C ; t_{(12)}=2.38, p=0.04$, independent samples $t$ test) and VGLUT2/VGAT (Fig. $6 C ; t_{(12)}=$ $2.84, p=0.015$, independent samples $t$ test), an indirect molecular measure used previously as a correlate of $\mathrm{E} / \mathrm{I}$ ratio (Hines et al., 2008), suggesting an imbalance between excitatory and inhibitory synapses. These findings of higher markers of presynaptic and postsynaptic glutamatergic spines but lower levels of postsynaptic glutamatergic proteins suggest that loss of Crbn dysregulates density and function of excitatory glutamatergic synapses.

\section{Pharmacological inhibition of exaggerated AMPK activity rescues learning and memory in $\mathrm{Crbn}^{\mathrm{KO}}$ mice}

To directly test whether the learning and memory deficits and changes in hippocampal synaptic protein levels in $\mathrm{Crbn}{ }^{\mathrm{KO}}$ mice is due to enhanced AMPK activity, adult $\mathrm{Crbn}{ }^{\mathrm{WT}}$ and $\mathrm{Crbn}{ }^{\mathrm{KO}}$ mice were treated with either Compound C (10 mg/kg, i.p.), a specific inhibitor of AMPK, or vehicle, $25 \mathrm{~min}$ before behavioral testing. Remarkably, in the water-based Y maze, Compound C was sufficient to rescue the learning and memory deficits observed in $C r b n^{\mathrm{KO}}$ mice. During training, as demonstrated previously (Fig. 2C), vehicle-treated $\mathrm{Crbn}{ }^{\mathrm{KO}}$ mice displayed learning deficits compared to $\mathrm{Crbn} n^{\mathrm{WT}}$ mice, while Compound C-treated $\mathrm{Crbn}{ }^{\mathrm{KO}}$ mice found the platform with a latency similar to that seen in $\mathrm{Crbn}{ }^{\mathrm{WT}}$ mice (Fig. 7A; main effect of trial, $F_{(6,140)}=5.90, p=$ $<0.0001$; main effect of Compound C, $F_{(3,140)}=10.82, p<$ 0.0001; two-way ANOVA). During the Y-maze probe test, vehicletreated $\mathrm{Crbn}^{\mathrm{KO}}$ mice displayed a memory deficit compared to 
A

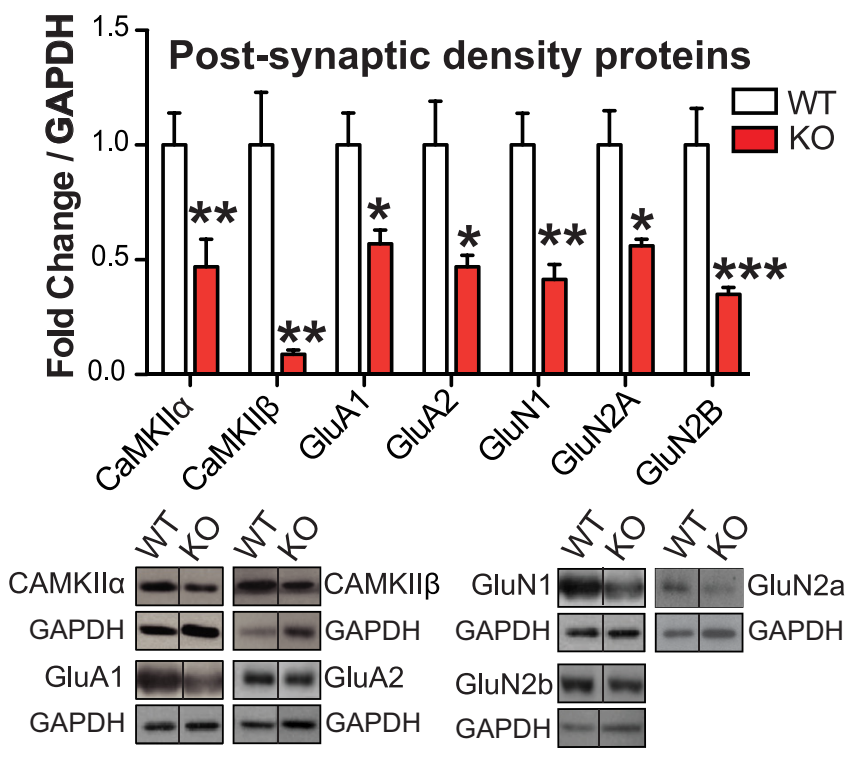

B

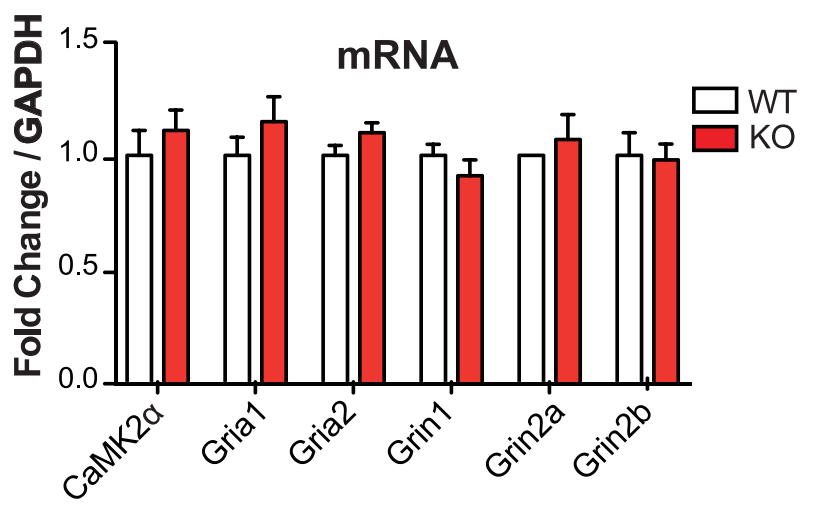

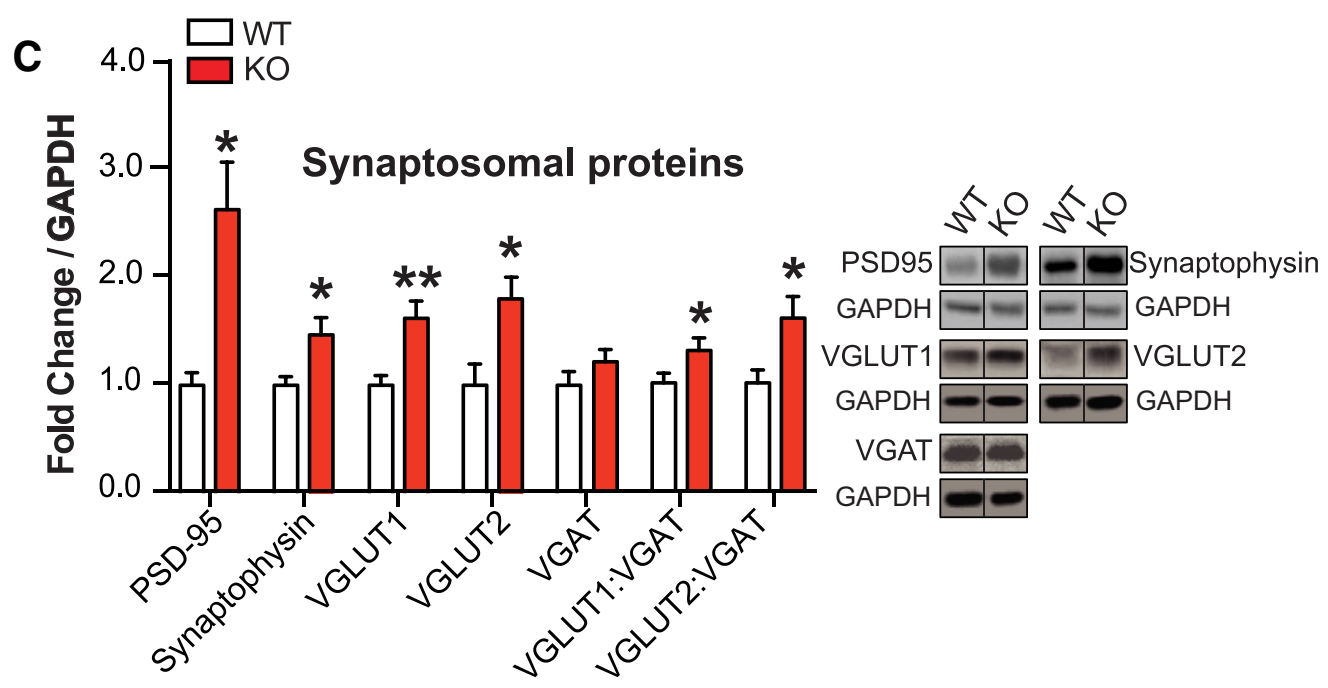

Figure 6. $\quad C r b n^{\mathrm{K} 0}$ mice show decreased levels of synaptic proteins in the hippocampus. A, PSD enriched hippocampal fractions from $\mathrm{Crbn}^{\mathrm{K} 0}$ mice showed lower protein levels of CaMKIll $\alpha\left(C r b n{ }^{\mathrm{WT}}\right.$,

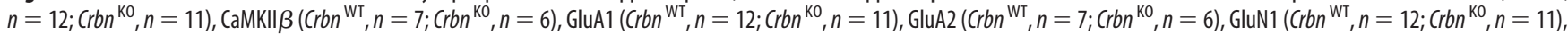
GluN2A ( $n=4 /$ genotype), and GluN2B ( $n=11 /$ genotype) compared to Crbn ${ }^{\text {WT }}$ mice. B, No differences were found in mRNA expression of Camk2a Gria1, Gria2, Grin1, Grin2a, or Grin2b in the hippocampi of $C r b n{ }^{\text {WT }}$ and $C r b n^{\mathrm{K} 0}$ mice ( $n=7 /$ genotype). C, Compared to $C r b n{ }^{\text {WT }}$ mice, $C r b n{ }^{\mathrm{K} 0}$ mice displayed significantly increased synaptosomal protein levels of PSD-95 (Crbn ${ }^{\mathrm{WT}}, n=7$; $\mathrm{Crbn}^{\mathrm{K} 0}, n=6$ ), synaptophysin ( $\mathrm{Crbn}{ }^{\mathrm{WT}}, n=6$; $\mathrm{Crbn}^{\mathrm{K} 0}, n=7$ ), VGLUT1 ( $n=7$ /genotype), and VGLUT2 ( $n=7 /$ genotype), with no change in VGAT expression observed between genotypes ( $n=$ 7/genotype). Crbn ${ }^{\mathrm{KO}}$ mice displayed a significantly higher VGLUT1/VGAT ratio and VGLUT2/NGAT ratio compared to Crbn ${ }^{\mathrm{WT}}$ mice $\left(n=7 /\right.$ genotype). ${ }^{*} p<0.05 ;{ }^{* *} p<0.01 ;{ }^{* * *} p<0.001$. Data displayed as mean \pm SEM. Western blot images are representative samples taken from the same blot.

$\mathrm{Crbn}{ }^{\mathrm{WT}}$ mice, while Compound C-treated mice found the platform with a latency similar to that of $C r b n^{\text {WT }}$ mice (Fig. $7 B$; significant interaction of genotype $\times$ drug, $F_{(1,20)}=4.75, p=0.04$, two-way ANOVA). Of note, Compound Chad no effect on learning (Fig. 6A) or memory (Fig. $6 B$ ) in Crbn ${ }^{\mathrm{WT}}$ mice.

In a test for contextual fear memory, vehicle-treated $\mathrm{Cr} b n^{\mathrm{KO}}$ mice froze significantly less than $\mathrm{Crbn}{ }^{\mathrm{WT}}$ mice, while Compound C-treated $C r b n^{\mathrm{KO}}$ mice froze as much as $\mathrm{Crbn}{ }^{\mathrm{WT}}$ mice (Fig. 7C; significant interaction of genotype $\times$ drug, $F_{(1,18)}=6.57, p=$ 0.02 , two-way ANOVA), indicating a rescue of deficient contextual memory by Compound C. The drug had no effect in $\mathrm{Crbn}{ }^{\mathrm{WT}}$ mice.
Pharmacological inhibition of exaggerated AMPK activity normalizes mediators of mTORC1 translation initiation pathway and postsynaptic glutamatergic proteins

Next, we tested whether Compound C could normalize the reduced levels of hippocampal proteins observed in $\mathrm{Crbn}{ }^{\mathrm{KO}}$ mice. Behaviorally tested $\mathrm{Crbn}{ }^{\mathrm{WT}}$ and $\mathrm{Crbn}{ }^{\mathrm{KO}}$ mice were treated with either vehicle or Compound C, and bilateral dorsal hippocampus were dissected $25 \mathrm{~min}$ later. Treatment with Compound $\mathrm{C}$ reduced p-AMPK in $C r b n^{\mathrm{KO}}$ mice to levels similar to those in $\mathrm{Crbn}{ }^{\mathrm{WT}}$ mice (Fig. $7 D$; significant interaction of genotype $\times$ Compound $C, F_{(1,18)}=$ $4.43, p=0.05$ ), with a corresponding increase in mTORC1 activity (Fig. $7 D$; main effect of genotype, $F_{(1,16)}=4.65, p=0.047$; main 

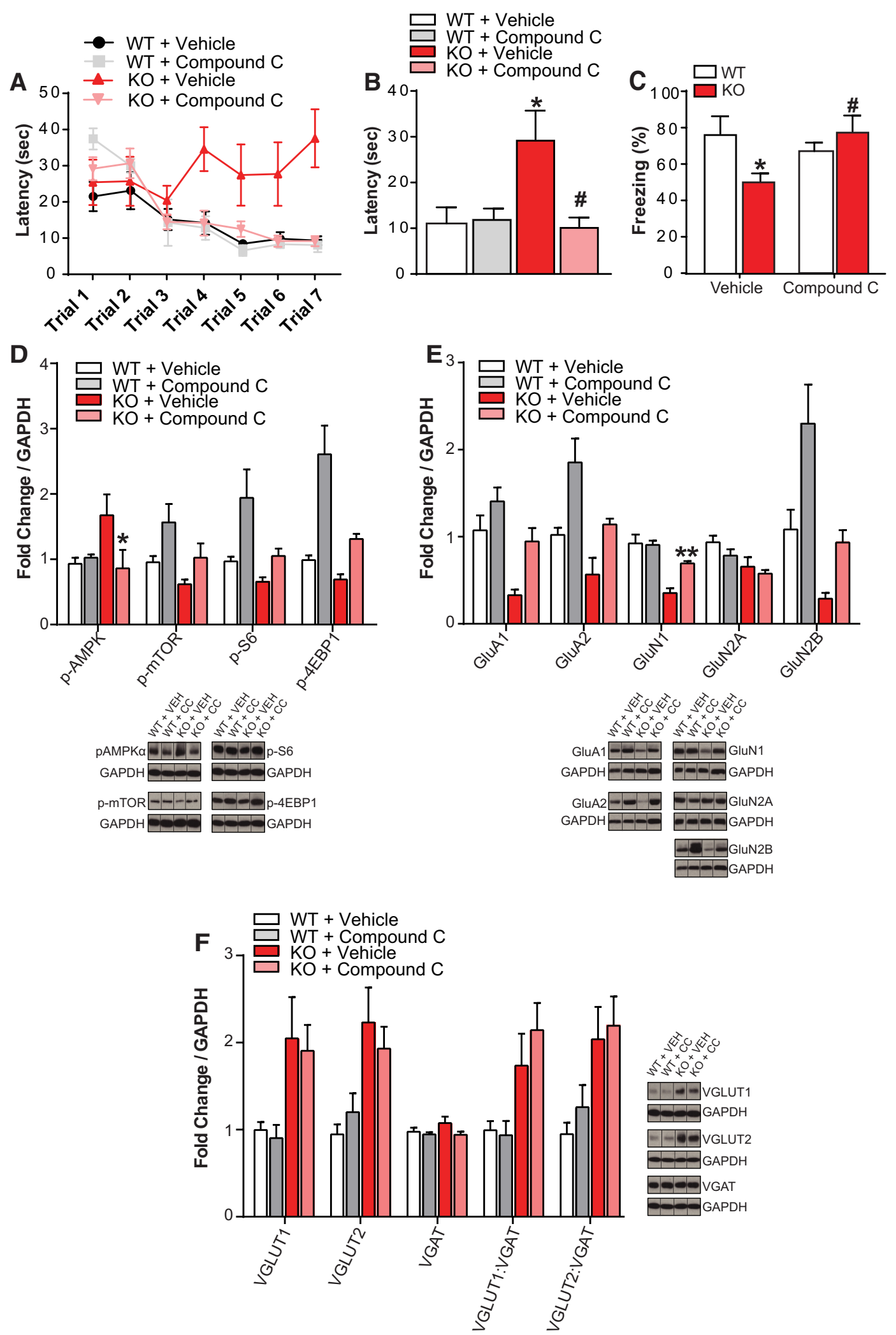

Figure 7. Pharmacological inhibition of AMPK rescues learning and memory deficits in $\mathrm{Crbn}^{\mathrm{K} 0}$ mice. A, During the Y-maze training, Compound $\mathrm{C}-$ treated $\mathrm{Crbn}{ }^{\mathrm{K} 0}$ mice displayed decreased latency to find the hidden platform compared to vehicle-treated $\mathrm{Crbn}^{\mathrm{KO}}$ mice, similar to the level observed in $\mathrm{Crbn}^{\mathrm{WT}}$ mice. Compound Chad no effect on latency in $\mathrm{Crbn}{ }^{\mathrm{WT}}$ mice (Crbn ${ }^{\mathrm{WT}}+$ vehicle, $n=8 ; C r b n^{\mathrm{WT}}+$ Compound C, $n=4 ;\left(r b n^{\mathrm{K} 0}+\right.$ vehicle, $n=7 ; \mathrm{Crb}^{\mathrm{K} 0}+$ Compound C, $\left.n=5\right) . \boldsymbol{B}$, During the Y-maze probe test, treatment with Compound C significantly reduced the latency

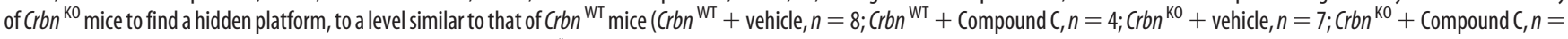
5). ${ }^{*} p<0.05$ (Bonferroni post hoc test, WT + vehicle vs KO vehicle); ${ }^{\#} p<0.05$ (Bonferroni post hoc test, $\mathrm{KO}+$ vehicle vs $\mathrm{KO}+$ Compound C). C, In a test of contextual fear conditioning, treatment

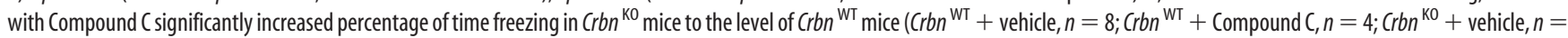

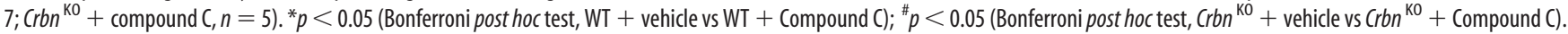
D. Treatment with Compound ( decreased synaptosomal expression of phosphorylated AMPK in Crbn ${ }^{\mathrm{K} 0}$ mice but not in Crbn ${ }^{\mathrm{WT}}$ mice (Crbn ${ }^{\mathrm{WT}}+$ vehicle, (Figure legend continues.) 
effect of Compound C, $\left.F_{(1,16)}=6.29, p=0.023\right)$ and downstream expression of phosphorylated S6 (Fig. 7D; main effect of genotype, $F_{(1,18)}=5.74, p=0.03$; main effect of Compound $\mathrm{C}$, $F_{(1,18)}=7.45, p=0.01$ ) and phosphorylated 4E-BP1 (Fig. 7D; main effect of genotype, $F_{(1,16)}=10.93, p=0.005$; main effect of Compound $\left.C, F_{(1,16)}=21.57, p=0.0003\right)$. Examination of PSD glutamatergic proteins revealed that in $\mathrm{Crbn} n^{\mathrm{KO}}$ mice, Compound C increased PSD protein levels of GluA1 (Fig. 7E; main effect of genotype, $F_{(1,18)}=17.06, p=0.0006$; main effect of Compound C, $F_{(1,18)}=10.68, p=0.004$ ), GluA2 (Fig. $7 E$; main effect of genotype, $F_{(1,18)}=10.43, p=0.005$; main effect of Compound $C$, $F_{(1,18)}=15.27, p=0.001$ ), GluN1 (Fig. $7 E$; significant interaction of genotype $\times$ Compound $\left.C, F_{(1,18)}=9.25, p=0.007\right)$, and GluN2B (Fig. $7 E$; main effect of genotype, $F_{(1,18)}=14.93, p=0.001$; main effect of Compound C, $F_{(1,18)}=11.1, p=0.004$ ), with no effect on GluN2A (Fig. 7E).

Interestingly, treatment with Compound $\mathrm{C}$ had no effect on the higher synaptosomal protein levels of excitatory presynaptic markers VGLUT1 (Fig. 7F; main effect of genotype, $F_{(1,18)}=$ $13.16, p=0.002$ ) and VGLUT2 (Fig. 7F; main effect of genotype, $\left.F_{(1,18)}=14.82, p=0.001\right)$ in $C r b n^{\mathrm{KO}}$ mice, and did not alter inhibitory presynaptic marker VGAT (Fig. $7 F$ ) or the ratio of VGLUT1/VGAT (Fig. 7F; main effect of genotype, $F_{(1,17)}=15.24$, $p=0.001)$ or VGLUT2/VGAT (Fig. $7 F ; F_{(1,17)}=12.68, p=$ 0.002 ), suggesting that normalization of postsynaptic glutamatergic proteins is sufficient to rescue behavioral deficits in $\mathrm{Crbn}{ }^{\mathrm{KO}}$ mice.

In $\mathrm{Crbn}{ }^{\mathrm{WT}}$ mice, even though no effect of Compound $\mathrm{C}$ on basal p-AMPK levels was observed (based on detection by Western blot analysis), it robustly increased p-S6 and p-4E-BP1 levels (Fig. 7D), as well as GluA1, GluA2, and GluN2B (Fig. 7E), with no effect on VGLUT1, VGLUT2, or VGAT (Fig. $7 F$ ). However, interestingly, the increase in these glutamatergic proteins by Compound $\mathrm{C}$ in $\mathrm{Crbn} n^{\mathrm{WT}}$ mice did not enhance learning or memory in the Y maze (Fig. 7A, B) or contextual fear conditioning (Fig. 7C).

\section{Discussion}

In this study, we establish the $\mathrm{Crbn}{ }^{\mathrm{KO}}$ mouse model as a model of intellectual disability, with deficits in hippocampal-dependent learning and memory behaviors and hippocampal synaptic plasticity, revealed by deficits in LTP and synaptic protein expression. These mice demonstrate normal working memory and social behaviors and show no repetitive behaviors. $\mathrm{Crbn}{ }^{\mathrm{KO}}$ mice additionally do not exhibit altered anxiety-like behavior (Rajadhyaksha et al., 2012). Importantly, the learning- and memory-related behav-

$\leftarrow$

(Figure legend continued.) $n=5 ;\left(r b n^{\mathrm{WT}}+\right.$ Compound C, $n=6$; $\mathrm{Crbn}^{\mathrm{K} 0}+$ vehicle, $n=5$ $\mathrm{Crbn}^{\mathrm{K} 0}+$ compound $\mathrm{C}, n=6$ ). Treatment with Compound $\mathrm{C}$ increased phosphorylated mTORC1 (WT + vehicle, $n=5$; WT + Compound C, $n=5$; KO + vehicle, $n=4$; KO + Compound C, $n=6$ ), phosphorylated S6 (WT + vehicle, $n=5 ;$ WT + Compound C, $n=6$; $\mathrm{K} 0+$ vehicle, $n=5 ; \mathrm{KO}+$ Compound $\mathrm{C}, n=6$ ), and phosphorylated 4E-BP1 (WT + vehicle, $n=5 ; \mathrm{WT}+$ Compound C, $n=5 ; \mathrm{KO}+$ vehicle, $n=5 ; \mathrm{KO}+$ Compound $\mathrm{C}, n=4)$ in $\mathrm{Crbn}^{\mathrm{WT}}$ and $\mathrm{Crbn}^{\mathrm{K} 0}$ mice. ${ }^{*} p<0.05$ (Bonferroni post hoc test, $\mathrm{Crbn}^{\mathrm{K} 0}+$ vehicle vs $\mathrm{Crbn}^{\mathrm{K} 0}+\mathrm{Com}$ pound C). $\boldsymbol{E}$, Treatment with Compound (increased protein levels of GluA1, GluA2, and GluN2B, but not GluN2A (WT + vehicle, $n=5 ; \mathrm{WT}+$ Compound C, $n=6 ; \mathrm{KO}+$ vehicle, $n=5 ; \mathrm{KO}+$ Compound $C, n=6)$ in the hippocampal PSD of $C r b n{ }^{\text {WT }}$ and $C r b n^{\mathrm{K} 0}$ mice, and increased expression of GluN1 in $\mathrm{Crbn}^{\mathrm{KO}}$ mice. ${ }^{* *} p<0.01$ (Bonferroni post hoc test, $\mathrm{KO}+$ vehicle vs $\mathrm{KO}+$ Compound C). $\boldsymbol{F}$, Treatment with Compound ( did not alter synaptosomal protein levels of VGLUT1 or VGLUT2 in $\mathrm{Crbn}^{\mathrm{WT}}$ or Crbn ${ }^{\mathrm{K} 0}$ mice (WT + vehicle, $n=5$; WT + Compound $\mathrm{C}, n=$ $6 ; \mathrm{KO}+$ vehicle, $n=5 ; \mathrm{KO}+$ Compound $\mathrm{C}, n=6)$, nor did it alter the ratio of VGLUT1/VGAT or VGLUT2/VGAT (WT + vehicle, $n=5 ; \mathrm{WT}+$ Compound C, $n=6 ; \mathrm{KO}+$ vehicle, $n=5 ; \mathrm{KO}+$ Compound $C, n=5)$. Data are displayed as mean \pm SEM. Western blot images are representative samples taken from the same blot. ioral deficits observed in $\mathrm{Crbn} n^{\mathrm{KO}}$ mice can be recapitulated by focal deletion of Crbn within the dorsal hippocampus, and impairments in hippocampal chemical LTP can be rescued by overexpression of human CRBN, suggesting a critical role of Crbn specifically within the hippocampus. In agreement with a previous report (Lee et al., 2014), molecular studies confirm that $\mathrm{Crbn}{ }^{\mathrm{KO}}$ mice have exaggerated levels of phosphorylated AMPK $\alpha$ in the hippocampus, in parallel with downregulation of the mTORC1 pathway, a downstream target of AMPK. We extend these findings to show that these molecular changes occur within hippocampal dendritic neurosynaptosomes. We further demonstrate a specific deficit in synaptosomal mTORC1-mediated mRNA translation initiation factors with no effect on the mRNA elongation factor eEF2. We show that, as opposed to other rodent models with memory deficits, we find no effect of loss of Crbn on AMPKregulated UPR or autophagy pathways.

Consistent with a defect in dendritic mTORC1 mRNA translation, examination of hippocampal postsynaptic density proteins in $\mathrm{Crbn}{ }^{\mathrm{KO}}$ mice finds significantly lower levels of glutamatergic signaling proteins known to be critical mediators of learning and memory. Interestingly, using molecular dendritic synaptosomal spine markers, we find that Crbn deficiency leads to higher levels of excitatory glutamatergic synapses, with no change in inhibitory GABAergic synapses, suggesting dysgenesis and dysfunction of glutamatergic synapses. Importantly, we find that behavioral and molecular deficits observed in these mice can be corrected by treatment of adult $\mathrm{Crbn}{ }^{\mathrm{KO}}$ mice with the AMPK inhibitor, Compound $\mathrm{C}$, indicating that enhanced AMPK phosphorylation mediates the intellectual disability-related phenotype in these mice. Taken together, these findings establish the $\mathrm{Crbn}^{\mathrm{KO}}$ mouse as a useful model to further study the fundamental cellular and molecular mechanisms of learning and memory with no confounding behavioral or molecular phenotypes often associated with current models of ID.

\section{$\mathrm{Crbn}^{\mathrm{KO}}$ mice as a model of ID}

The specific deficits in learning and memory in the Morris water maze and the water-based $\mathrm{Y}$ maze, in addition to our previous report of deficient contextual fear memory in $\mathrm{Crbn}^{\mathrm{KO}}$ mice (Rajadhyaksha et al., 2012), are consistent with the pure ID phenotype observed in humans with ARNSID. Previous studies have shown that CRBN is the primary target of thalidomide (Ito et al., 2010), a compound known for its teratogenic effects on the developing fetus. ASDs have been associated with fetal exposure to thalidomide at 20-24 d gestation (Strömland et al., 1994) and variations in CRBN copy number (Pinto et al., 2010). While $\mathrm{Crbn}^{\mathrm{KO}}$ mice show hippocampal-dependent learning and memory deficits, they do not demonstrate changes in social or repetitive behavior, and, as reported previously by Rajadhyaksha et al. (2012), they show unaltered anxiety-like behavior, hallmarks of ASDs. The absence of these behaviors in $\mathrm{Crbn}{ }^{\mathrm{KO}}$ mice suggests that the $\mathrm{Crbn}^{\mathrm{KO}}$ mouse is a model to study isolated intellectual disability (Higgins et al., 2000, 2004a, b).

\section{AMPK, mTORC1, learning/memory, and synaptic plasticity} AMPK $\alpha$, the predominant brain-specific AMPK catalytic subunit, is highly expressed selectively in neurons in the hippocampus (Han et al., 2016), but studies describing the role of AMPK $\alpha$ in learning and memory behaviors and synaptic plasticity remain sparse. Our results show that heighted AMPK activity via hyperphosphorylated AMPK $\alpha$ (p-AMPK) in the hippocampus of $C r b n^{\mathrm{KO}}$ mice correlates with hippocampal-dependent learning and memory behavioral deficits as well as altered synaptic protein levels, and 
that pharmacological inhibition of p-AMPK in adult $\mathrm{Crbn} n^{\mathrm{KO}}$ mice can correct these deficits. These data are consistent with the finding that pharmacological and genetic enhancement of AMPK in the CA1 impairs long-term fear memory (Han et al., 2016) and spatial memory formation (Dash et al., 2006), while pharmacological correction of higher p-AMPK mends CA1 LTP deficits in an AD mouse model (Ma et al., 2014).

Consistent with hyperphosphorylated AMPK $\alpha$, we find decreased mTORC1 signaling in synaptosomal fractions of the $\mathrm{Crbn}{ }^{\mathrm{KO}}$ hippocampus. A number of ID-associated neurodevelopmental disorders have been linked to aberrant mTOR activity (Huber et al., 2015); while hyperactivation of mTOR has been linked to disorders such as fragile $\mathrm{X}$ syndrome and tuberous sclerosis, our finding of lower mTORC1 signaling in the $\mathrm{Crbn}{ }^{\mathrm{KO}}$ mice mirrors lower MTORC1 signaling observed in the MeCP2 knock-out Rett syndrome mouse model, a neurodevelopmental disorder associated with ID and dendritic spine abnormalities (Troca-Marín et al., 2012). Consistent with a role of the mTOR pathway in mediating local dendritic mRNA translation of proteins in excitatory synapses (Buffington et al., 2014), a process required for LTP and memory formation (Santini and Klann, 2014), we find that decreased mTORC1 activity and its downstream translation initiation proteins are associated with lower levels of synaptic glutamatergic AMPA (GluA1 and GluA2) and NMDA receptor subunits (GluN1, GluN2A, and GluN2B) in the hippocampi of adult $\mathrm{Crbn}^{\mathrm{KO}}$ mice. This is in line with mTORC1-mediated translation regulating dendritic AMPAR and NMDAR translation (Troca-Marín et al., 2012; Huber et al., 2015) and spine dysgenesis (Huber et al., 2015; Phillips and Pozzo-Miller, 2015) linked to learning and memory. We show that Compound $\mathrm{C}$ is able to normalize levels of postsynaptic GluA1, GluA2, GluN1, and GluN2B in parallel with correcting behavioral deficits without normalizing GluN2A. The lack of effect of Compound C on GluN2A levels suggests that GluN2B-containing NMDARs may be critical for the rescue of learning and memory in $\mathrm{Crbn}{ }^{\mathrm{KO}}$ mice. Even though studies on GluN2B and learning/memory remain limited, our finding is consistent with genetic variants in the GluN2B gene, GRIN2B, being linked to ID (Hu et al., 2016). GluN2B subunit expression predominates during early development, with a critical role in neuronal circuit development and synaptic plasticity (Cohen and Greenberg, 2008), and transgenic mice overexpressing GluN2B demonstrate enhanced hippocampal LTP and learning/memory in contextual fear conditioning and the Morris water maze when tested during adulthood (Tang et al., 1999). Future studies will address the sufficiency of GluN2B-containing NMDARs in rescuing learning/memory deficits in $\mathrm{Crbn}{ }^{\mathrm{KO}}$ mice. Given our chemical LTP data showing that NMDAR-dependent trafficking of GluA1 is altered in cultured hippocampal neurons from $\mathrm{Crbn}{ }^{\mathrm{KO}}$ mice, we additionally hypothesize that dysfunction of NMDAR neurotransmission and trafficking of AMPARs may underlie the deficits in learning and memory observed in $\mathrm{Crbn} n^{\mathrm{KO}}$ mice. Future studies will further parse out the sufficiency of AMPA versus NMDA receptors for correcting behavior.

Surprisingly, other AMPK-regulated pathways are unaltered in the hippocampus as a consequence of Crbn deficiency, including the eEF2K/eEF2 mRNA elongation pathway, the UPR system, and autophagy, all previously linked to memory deficits particularly in neurodegenerative animal models (Ma et al., 2014; Maiese, 2016; Remondelli and Renna, 2017). In particular, the lack of changes in phosphorylated eIF $2 \alpha$, which we used as a marker of UPR activation, was unexpected because cultured mouse embryonic fibroblasts generated from $\mathrm{Crbn}{ }^{\mathrm{KO}}$ mice show enhanced phosphorylation of eIF $2 \alpha$ and its kinase PKR-like ER kinase (Lee et al.,
2015). The discrepancy could be attributable to use of cultured embryonic fibroblasts versus adult hippocampus. Additionally, the lack of alteration of the above pathways as a consequence of hyperphosphorylated AMPK in $\mathrm{Crbn}{ }^{\mathrm{KO}}$ mice may reflect differential mechanisms contributing to memory deficits in neurodegenerative disorders versus those involved in developmental disorders such as intellectual disability. Based on our findings, deficits in $\mathrm{Crbn}{ }^{\mathrm{KO}}$ mice appear to be specific to AMPK-mediated inhibition of mTORC1 mRNA initiation pathway.

We also found an increase in excitatory glutamatergic presynaptic (VGLUT1/2) markers in $\mathrm{Crbn}^{\mathrm{KO}}$ mice and an overall increase in E/I balance, measured as a ratio of VGLUT1/2 over VGAT, observed in several animal models of learning and memory (Verpelli et al., 2014; Gao and Penzes, 2015; Mullins et al., 2016). Interestingly, inhibition of AMPK hyperactivity in $\mathrm{Crbn}{ }^{\mathrm{KO}}$ mice that corrected behavioral deficits did not normalize the higher levels of the excitatory spine markers, suggesting that normalizing postsynaptic changes is sufficient to rescue behavior in adult $\mathrm{Crbn}{ }^{\mathrm{KO}}$ mice. Whether glutamatergic postsynaptic changes correct imbalances in E/I neurotransmission observed in several ID (Verpelli et al., 2014; Gao and Penzes, 2015; Mullins et al., 2016) and other neurodevelopmental mouse models (Gao and Penzes, 2015; Nelson and Valakh, 2015) remains unknown and will be addressed in future studies. The lack of an effect of Compound $\mathrm{C}$ on spine markers in $\mathrm{Crbn}{ }^{\mathrm{KO}}$ mice and particularly $\mathrm{Crbn}{ }^{\mathrm{WT}}$ mice suggests that AMPK may not directly regulate levels of presynaptic markers. A possible reason for heightened presynaptic excitatory spine markers could be dysregulation of an alternative Crbn mechanism such as the ubiquitination pathway, given Crbn's role as an E3 ubiquitin ligase substrate (Ito et al., 2010; Chang and Stewart, 2011). Supporting this hypothesis, it is interesting to highlight these recent findings suggesting that CRBN may mediate ubiquitination of presynaptic proteins, including VGLUT1. Importantly, though, Compound $\mathrm{C}$ was able to rescue learning and memory-related behaviors without impacting these spine markers, suggesting that specifically targeting mTOR-mediated mRNA translation of postsynaptic glutamatergic proteins can improve cognitive deficits even when changes in spine dynamics are not altered.

In summary, our results support a model in which the loss of Crbn leads to hyperactivity of AMPK, resulting in a decrease in dendritic mTOR-mediated mRNA translation in the hippocampus, dysregulated glutamatergic signaling, and learning and memory deficits that can be corrected by pharmacologically targeting hyperactive AMPK in adult $\mathrm{CrbnKO}$ mice.

\section{References}

Amato S, Liu X, Zheng B, Cantley L, Rakic P, Man HY (2011) AMPactivated protein kinase regulates neuronal polarization by interfering with PI 3-kinase localization. Science 332:247-251. CrossRef Medline

Appenzeller-Herzog C, Hall MN (2012) Bidirectional crosstalk between endoplasmic reticulum stress and mTOR signaling. Trends Cell Biol 22: 274-282. CrossRef Medline

Beaudoin GM 3rd, Lee SH, Singh D, Yuan Y, Ng YG, Reichardt LF, Arikkath J (2012) Culturing pyramidal neurons from the early postnatal mouse hippocampus and cortex. Nat Protoc 7:1741-1754. CrossRef Medline

Buffington SA, Huang W, Costa-Mattioli M (2014) Translational control in synaptic plasticity and cognitive dysfunction. Annu Rev Neurosci 37:1738. CrossRef Medline

Burgdorf CE, Schierberl KC, Lee AS, Fischer DK, Van Kempen TA, Mudragel V, Huganir RL, Milner TA, Glass MJ, Rajadhyaksha AM (2017) Extinction of contextual cocaine memories requires $\mathrm{Ca}_{\mathrm{v}} 1.2$ within D1Rexpressing cells and recruits hippocampal $\mathrm{Ca}_{\mathrm{v}} 1.2$-dependent signaling mechanisms. J Neurosci 37:11894-11911. CrossRef Medline

Chang XB, Stewart AK (2011) What is the functional role of the thalidomide binding protein cereblon? Int J Biochem Mol Biol 2:287-294. Medline

Cohen S, Greenberg ME (2008) Communication between the synapse and 
the nucleus in neuronal development, plasticity, and disease. Annu Rev Cell Dev Biol 24:183-209. CrossRef Medline

Dash PK, Orsi SA, Moore AN (2006) Spatial memory formation and memory-enhancing effect of glucose involves activation of the tuberous sclerosis complex-mammalian target of rapamycin pathway. J Neurosci 26:8048-8056. CrossRef Medline

Del Prete D, Rice RC, Rajadhyaksha AM, D’Adamio L (2016) Amyloid precursor protein (APP) may act as a substrate and a recognition unit for CRL4CRBN and Stub1 E3 ligases facilitating ubiquitination of proteins involved in presynaptic functions and neurodegeneration. J Biol Chem 291:17209-17227. CrossRef Medline

Diering GH, Gustina AS, Huganir RL (2014) PKA-GluAl coupling via AKAP5 controls AMPA receptor phosphorylation and cell-surface targeting during bidirectional homeostatic plasticity. Neuron 84:790805. CrossRef Medline

Gao R, Penzes P (2015) Common mechanisms of excitatory and inhibitory imbalance in schizophrenia and autism spectrum disorders. Curr Mol Med 15:146-167. CrossRef Medline

Graber TE, McCamphill PK, Sossin WS (2013) A recollection of mTOR signaling in learning and memory. Learn Mem 20:518-530. CrossRef Medline

Han Y, Luo Y, Sun J, Ding Z, Liu J, Yan W, Jian M, Xue Y, Shi J, Wang JS, Lu L (2016) AMPK signaling in the dorsal hippocampus negatively regulates contextual fear memory formation. Neuropsychopharmacology 41 : 1849-1864. CrossRef Medline

Hardie DG (2004) The AMP-activated protein kinase pathway-new players upstream and downstream. J Cell Sci 117:5479-5487. CrossRef Medline

Hardie DG, Ross FA, Hawley SA (2012) AMP-activated protein kinase: a target for drugs both ancient and modern. Chem Biol 19:1222-1236. CrossRef Medline

Hegde AN (2017) Proteolysis, synaptic plasticity and memory. Neurobiol Learn Mem 138:98-110. Medline

Higgins JJ, Rosen DR, Loveless JM, Clyman JC, Grau MJ (2000) A gene for nonsyndromic mental retardation maps to chromosome 3p25-pter. Neurology 55:335-340. CrossRef Medline

Higgins JJ, Pucilowska J, Lombardi RQ, Rooney JP (2004a) Candidate genes for recessive non-syndromic mental retardation on chromosome $3 \mathrm{p}$ (MRT2A). Clin Genet 65:496-500. CrossRef Medline

Higgins JJ, Pucilowska J, Lombardi RQ, Rooney JP (2004b) A mutation in a novel ATP-dependent Lon protease gene in a kindred with mild mental retardation. Neurology 63:1927-1931. CrossRef Medline

Higgins JJ, Tal AL, Sun X, Hauck SC, Hao J, Kosofosky BE, Rajadhyaksha AM (2010) Temporal and spatial mouse brain expression of cereblon, an ionic channel regulator involved in human intelligence. J Neurogenet 24:18-26. CrossRef Medline

Hines RM, Wu L, Hines DJ, Steenland H, Mansour S, Dahlhaus R, Singaraja RR, Cao X, Sammler E, Hormuzdi SG, Zhuo M, El-Husseini A (2008) Synaptic imbalance, stereotypies, and impaired social interactions in mice with altered neuroligin 2 expression. J Neurosci 28:6055-6067. CrossRef Medline

Hoeffer CA, Klann E (2010) mTOR signaling: at the crossroads of plasticity, memory and disease. Trends Neurosci 33:67-75. CrossRef Medline

Horman S, Browne G, Krause U, Patel J, Vertommen D, Bertrand L, Lavoinne A, Hue L, Proud C, Rider M (2002) Activation of AMP-activated protein kinase leads to the phosphorylation of elongation factor 2 and an inhibition of protein synthesis. Curr Biol 12:1419-1423. CrossRef Medline

Hu C, Chen W, Myers SJ, Yuan H, Traynelis SF (2016) Human GRIN2B variants in neurodevelopmental disorders. J Pharmacol Sci 132:115-121. CrossRef Medline

Huber KM, Klann E, Costa-Mattioli M, Zukin RS (2015) Dysregulation of mammalian target of rapamycin signaling in mouse models of autism. J Neurosci 35:13836-13842. CrossRef Medline

Hussain NK, Diering GH, Sole J, Anggono V, Huganir RL (2014) Sorting nexin 27 regulates basal and activity-dependent trafficking of AMPARs. Proc Natl Acad Sci U S A 111:11840-11845. CrossRef Medline

Inoki K, Zhu T, Guan KL (2003) TSC2 mediates cellular energy response to control cell growth and survival. Cell 115:577-590. CrossRef Medline

Ito T, Ando H, Suzuki T, Ogura T, Hotta K, Imamura Y, Yamaguchi Y, Handa H (2010) Identification of a primary target of thalidomide teratogenicity. Science 327:1345-1350. CrossRef Medline

Khan MA, Khan S, Windpassinger C, Badar M, Nawaz Z, Mohammad RM (2016) The molecular genetics of autosomal recessive nonsyndromic in- tellectual disability: a mutational continuum and future recommendations. Ann Hum Genet 80:342-368. CrossRef Medline

Kim HK, Ko TH, Nyamaa B, Lee SR, Kim N, Ko KS, Rhee BD, Park CS, Nilius B, Han J (2016) Cereblon in health and disease. Pflugers Arch 468:1299_ 1309. CrossRef Medline

Kim HJ, Cho MH, Shim WH, Kim JK, Jeon EY, Kim DH, Yoon SY (2017) Deficient autophagy in microglia impairs synaptic pruning and causes social behavioral defects. Mol Psychiatry 22:1576-1584. Medline

Kiriyama Y, Nochi H (2015) The function of autophagy in neurodegenerative diseases. Int J Mol Sci 16:26797-26812. CrossRef Medline

Knackstedt LA, Moussawi K, Lalumiere R, Schwendt M, Klugmann M, Kalivas PW (2010) Extinction training after cocaine self-administration induces glutamatergic plasticity to inhibit cocaine seeking. J Neurosci 30:7984-7992. CrossRef Medline

Leal G, Comprido D, Duarte CB (2014) BDNF-induced local protein synthesis and synaptic plasticity. Neuropharmacology 76:639-656. CrossRef Medline

Lee KM, Yang SJ, Choi JH, Park CS (2014) Functional effects of a pathogenic mutation in cereblon (CRBN) on the regulation of protein synthesis via the AMPK-mTOR cascade. J Biol Chem 289:23343-23352. CrossRef Medline

Lee KM, Yang SJ, Park S, Choi YD, Shin HK, Pak JH, Park CS, Kim I (2015) Depletion of the cereblon gene activates the unfolded protein response and protects cells from ER stress-induced cell death. Biochem Biophys Res Commun 458:34-39. CrossRef Medline

Li N, Lee B, Liu RJ, Banasr M, Dwyer JM, Iwata M, Li XY, Aghajanian G, Duman RS (2010) mTOR-dependent synapse formation underlies the rapid antidepressant effects of NMDA antagonists. Science 329:959-964. CrossRef Medline

Liu-Bryan R, Terkeltaub R (2015) Emerging regulators of the inflammatory process in osteoarthritis. Nat Rev Rheumatol 11:35-44. CrossRef Medline

Ma T, Trinh MA, Wexler AJ, Bourbon C, Gatti E, Pierre P, Cavener DR, Klann E (2013) Suppression of eIF2alpha kinases alleviates Alzheimer's diseaserelated plasticity and memory deficits. Nat Neurosci 16:1299-1305. CrossRef Medline

Ma T, Chen Y, Vingtdeux V, Zhao H, Viollet B, Marambaud P, Klann E (2014) Inhibition of AMP-activated protein kinase signaling alleviates impairments in hippocampal synaptic plasticity induced by amyloid beta. J Neurosci 34:12230-12238. CrossRef Medline

Maiese K (2016) Targeting molecules to medicine with mTOR, autophagy and neurodegenerative disorders. Br J Clin Pharmacol 82:1245-1266. CrossRef Medline

Mairet-Coello G, Courchet J, Pieraut S, Courchet V, Maximov A, Polleux F (2013) The CAMKK2-AMPK kinase pathway mediates the synaptotoxic effects of abeta oligomers through tau phosphorylation. Neuron 78:94108. CrossRef Medline

Malenka RC (2003) The long-term potential of LTP. Nat Rev Neurosci 4:923-926. CrossRef Medline

Morris RG, Garrud P, Rawlins JN, O’Keefe J (1982) Place navigation impaired in rats with hippocampal lesions. Nature 297:681-683. CrossRef Medline

Malinow R, Malenka RC (2002) AMPA receptor trafficking and synaptic plasticity. Annu Rev Neurosci 25:103-126. CrossRef Medline

Mullins C, Fishell G, Tsien RW (2016) Unifying views of autism spectrum disorders: a consideration of autoregulatory feedback loops. Neuron 89: 1131-1156. CrossRef Medline

Nelson SB, Valakh V (2015) Excitatory/inhibitory balance and circuit homeostasis in autism spectrum disorders. Neuron 87:684-698. CrossRef Medline

Nicoll RA, Malenka RC (1999) Expression mechanisms underlying NMDA receptor-dependent long-term potentiation. Ann N Y Acad Sci 868:515525. CrossRef

Nixon RA (2006) Autophagy in neurodegenerative disease: friend, foe or turncoat? Trends Neurosci 29:528-535. CrossRef Medline

Paxinos G, Franklin K (2004) The mouse brain in stereotaxic coordinates. Boston: Elsevier Academic.

Phillips M, Pozzo-Miller L (2015) Dendritic spine dysgenesis in autism related disorders. Neurosci Lett 601:30-40. CrossRef Medline

Picard N, Bergan S, Marquet P, van Gelder T, Wallemacq P, Hesselink DA, Haufroid V (2016) Pharmacogenetic biomarkers predictive of the pharmacokinetics and pharmacodynamics of immunosuppressive drugs. Drug Monit 38 [Suppl. 1]:S57-S69.

Pinto D, Pagnamenta AT, Klei L, Anney R, Merico D, Regan R, Conroy J, 
Magalhaes TR, Correia C, Abrahams BS, Almeida J, Bacchelli E, Bader GD, Bailey AJ, Baird G, Battaglia A, Berney T, Bolshakova N, Bölte S, Bolton PF, et al (2010) Functional impact of global rare copy number variation in autism spectrum disorders. Nature 466:368-372. CrossRef Medline

Rajadhyaksha AM, Ra S, Kishinevsky S, Lee AS, Romanienko P, DuBoff M, Yang C, Zupan B, Byrne M, Daruwalla ZR, Mark W, Kosofsky BE, Toth M, Higgins JJ (2012) Behavioral characterization of cereblon forebrainspecific conditional null mice: a model for human non-syndromic intellectual disability. Behav Brain Res 226:428-434. CrossRef Medline

Remondelli P, Renna M (2017) The endoplasmic reticulum unfolded protein response in neurodegenerative disorders and its potential therapeutic significance. Front Mol Neurosci 10:187. CrossRef Medline

Rosso P, Fioramonti M, Fracassi A, Marangoni M, Taglietti V, Siteni S, Segatto M (2016) AMPK in the central nervous system: physiological roles and pathological implications. Res Rep Biol 7:1-13. CrossRef

Santini E, Klann E (2014) Reciprocal signaling between translational control pathways and synaptic proteins in autism spectrum disorders. Sci Signal 7:re10. CrossRef Medline

Silverman JL, Yang M, Lord C, Crawley JN (2010) Behavioural phenotyping assays for mouse models of autism. Nat Rev Neurosci 11:490-502. CrossRef Medline

Strömland K, Nordin V, Miller M, Akerström B, Gillberg C (1994) Autism in thalidomide embryopathy: a population study. Dev Med Child Neurol 36:351-356. Medline

Swiech L, Perycz M, Malik A, Jaworski J (2008) Role of mTOR in physiology and pathology of the nervous system. Biochim Biophys Acta 1784:116132. CrossRef Medline

Taha E, Gildish I, Gal-Ben-Ari S, Rosenblum K (2013) The role of eEF2 pathway in learning and synaptic plasticity. Neurobiol Learn Mem 105: 100-106. CrossRef Medline

Tang G, Gudsnuk K, Kuo SH, Cotrina ML, Rosoklija G, Sosunov A, Sonders MS, Kanter E, Castagna C, Yamamoto A, Yue Z, Arancio O, Peterson BS, Champagne F, Dwork AJ, Goldman J, Sulzer D (2014) Loss of mTORdependent macroautophagy causes autistic-like synaptic pruning deficits. Neuron 83:1131-1143. CrossRef Medline

Tang YP, Shimizu E, Dube GR, Rampon C, Kerchner GA, Zhuo M, Liu G, Tsien JZ (1999) Genetic enhancement of learning and memory in mice. Nature 401:63-69. CrossRef Medline

Troca-Marín JA, Alves-Sampaio A, Montesinos ML (2012) Deregulated mTOR-mediated translation in intellectual disability. Prog Neurobiol 96: 268-282. CrossRef Medline

Verpelli C, Galimberti I, Gomez-Mancilla B, Sala C (2014) Molecular basis for prospective pharmacological treatment strategies in intellectual disability syndromes. Dev Neurobiol 74:197-206. CrossRef Medline

Walczak M, Martens S (2013) Dissecting the role of the Atg12-Atg5-Atg16 complex during autophagosome formation. Autophagy 9:424-425. CrossRef Medline

Wietrzych M, Meziane H, Sutter A, Ghyselinck N, Chapman PF, Chambon P, Krezel W (2005) Working memory deficits in retinoid X receptor $\gamma$-deficient mice. Learn Mem 12:318-326. CrossRef Medline

Xia Y, Portugal GS, Fakira AK, Melyan Z, Neve R, Lee HT, Russo SJ, Liu J, Morón JA (2011) Hippocampal GluA1-containing AMPA receptors mediate context-dependent sensitization to morphine. J Neurosci 31: 16279-16291. CrossRef Medline

Xu G, Jiang X, Jaffrey SR (2013) A mental retardation-linked nonsense mutation in cereblon is rescued by proteasome inhibition. J Biol Chem 288: 29573-29585. CrossRef Medline 